\title{
Inner-shelf ocean dynamics and seafloor morphologic changes during
}

\section{Hurricane Sandy}

\author{
John C. Warner ${ }^{1}$, William C. Schwab ${ }^{1}$, Jeffrey H. List ${ }^{1}$, Ilgar Safak ${ }^{1}$, Maria Liste ${ }^{2}$; \\ Wayne Baldwin ${ }^{1}$
}

${ }^{1}$ Coastal and Marine Geology Program, U.S. Geological Survey, 384 Woods Hole Road, Woods Hole, MA, USA 02543; jcwarner@usgs.gov; bschwab@usgs.gov;

jlist@usgs.gov; isafak@usgs.gov; wbaldwin@usgs.gov

${ }^{2}$ Integrated Statistics, Woods Hole, MA, under contract to U.S. Geological Survey; mlistemunoz@usgs.gov

\section{Abstract}

16

Hurricane Sandy was one of the most destructive hurricanes in US history, making landfall on the New Jersey coast on Oct 30, 2012. Storm impacts included several barrier island breaches, massive coastal erosion, and flooding. While changes to the subaerial landscape are relatively easily observed, storm-induced changes to the adjacent shoreface and inner continental shelf are more difficult to evaluate. These regions provide a framework for the coastal zone, are important for navigation, aggregate resources, marine ecosystems, and coastal evolution. Oceanographic conditions and seafloor morphologic changes on the inner continental shelf during Hurricane Sandy are evaluated using both a coupled atmospheric-ocean-wave-sediment numerical modeling system and observation analysis from a series of geologic surveys and oceanographic instrument deployments focused on a region offshore of Fire Island, NY. The geologic investigations conducted in 2011 and 2014 revealed lateral movement of sedimentary structures of distances up to $450 \mathrm{~m}$ and in water depths up to $30 \mathrm{~m}$, and vertical changes in sediment thickness greater than $1 \mathrm{~m}$ in some locations. The modeling investigations utilize a system with grid refinement designed to simulate oceanographic conditions with progressively increasing resolutions for the entire US East Coast (5-km grid), the New York Bight (700-m grid), and offshore of Fire Island, NY (100-m grid). Model results in 
32 the New York Bight identify maximum storm surge of up to $3 \mathrm{~m}$, surface currents on the

33 order of $2 \mathrm{~ms}^{-1}$ along the New Jersey coast, waves up to $8 \mathrm{~m}$ in height, and bottom

34 stresses exceeding $10 \mathrm{~Pa}$. Flow down the Hudson Shelf Canyon is shown to result in

35 convergent sediment transport and deposition along its axis. Modeled sediment

36 redistribution along Fire Island showed erosion across the crests of inner shelf sand

37 ridges and sedimentation in adjacent troughs, consistent with the geologic observations.

39 Keywords: shoreface connected sand ridges, sediment transport; Fire Island, NY;

40 Hurricane Sandy; inner shelf; numerical modeling

\section{Introduction}

Recent extreme storm impacts on the US east coast include Hurricane Isabel in

44 2003, the extratropical system Nor'Ida in 2009, Hurricane Irene in 2011, and Hurricane

45 Sandy in 2012, one of the most costly and destructive storms in US history. Hurricane

46 Sandy developed into a tropical storm in the Caribbean Sea on October 22, 2012 and

47 intensified into a hurricane on October 24 as it traveled north across the Caribbean

48 Islands. The storm evolved through several cycles of intensity as it traveled along the US

49 east coast and eventually reached a Category 2 with winds exceeding $154 \mathrm{~km} / \mathrm{hr}$ (96

$50 \mathrm{mi} / \mathrm{hr}$ ) on October 29 well offshore of Cape Hatteras, NC. The storm then weakened to a

51 post tropical cyclone before making landfall around on October 29 at 2300 UTC with

52 winds on the order of $70 \mathrm{~km} / \mathrm{hr}$ (44 mi/hr) (Blake et al., 2013; Figure 1).

53 Assessment of the impact of Hurricane Sandy identified damage from winds,

54 flooding from rainfall and storm surge, and coastal erosion. The alterations to the coast

55 included massive redistribution of sediment in the coastal zone, reduction of dune

56 heights, and several barrier island breaches (e.g., Hapke et al., 2013; Sopkin et al., 2014).

57 These changes to the subaerial component of the coastal system can be evaluated, both

58 over the long-term and in response to severe storms, through the use of repetitive aerial

59 photographs and airborne lidar topographic surveys. However, changes to the adjacent

60 subaqueous regions, including the shoreface and inner continental shelf, are not as easily

61 assessed, even though they compose the fundamental framework of the coastal zone, and

62 are critical areas with regard to navigation, aggregate resources, marine habitats, and 
63 seafloor morphological evolution. The thickness and distribution of mobile sediments on

64 the inner continental shelf is poorly documented in most areas, and little is known about

65 how these sedimentary deposits are modified during high-energy events such as

66 extratropical storms and hurricanes. Understanding the form and magnitude of seafloor

67 morphologic change is critical to developing coastal sediment budgets, as well as

68 increasing our knowledge of how these processes are time-integrated into the decadal and

69 longer timescales of continental margin sedimentation (e.g., Riggs et al., 1995; Schwab et

70 al., 2013; Miselis and McNinch, 2006; Denny et al., 2013).

71 Observations of impacts to the seafloor in the coastal zone (including shoreface

72 and inner continental shelf) from hurricanes are sparse due to the logistical and

73 technological difficulty in data collection required for measuring seafloor changes (e.g.,

74 Goff et al., 2015; Schwab et al., 2015). Observations of oceanographic and sediment

75 transport conditions during hurricanes are also typically rare, and often observed by

76 chance (Wren and Leonard, 2005; Teague et al., 2007). However, these types of

77 observations are becoming more available as long-term instrumented ocean observatories

78 are sustained and new techniques using remote vehicles allow observations during the

79 events (e.g., Miles et al., 2015).

$80 \quad$ Numerical simulations of hurricanes and severe Nor'Easters are more readily

81 available, including predictions and forecasts, and have shown substantial improvements

82 over the past few decades primarily though improvements to coarse-grid, global models

83 (Goerss 2006; Marks and Shay 1998; Wang and Wu 2004; Bender et al. 2007). Forecasts

84 of hurricane tracks have shown gradual improvements over the years, primarily attributed

85 to several research areas including improved assimilation of satellite and aircraft

86 observations, better representation of the hurricane vortex, and improved representation

87 of tropical physics (Rogers et al., 2006). However, improvement in tropical cyclone

88 intensity prediction has been slower to develop (Rogers et al., 2006; Wada et al., 2010),

89 often attributed to deficiencies of numerical models in three areas: coarse grid spacing,

90 poor formulations of the surface and boundary layers, and lack of coupling to a dynamic

91 ocean (Chen et al., 2007).

92 Developments of coupled modeling systems have progressed recently, with a full

93 review of recent advances and core technical and scientific issues summarized by Peng et 
94 al. (2012). A main advantage of coupling an ocean, sea ice, or wave model to an

95 atmosphere model is that they provide the atmosphere with dynamic feedbacks of sea

96 surface temperatures and surface roughness for momentum and heat flux computations.

97 These in turn modify the atmospheric processes and feedback to the ocean and wave

98 dynamics. Model coupling has been shown to increase predictability of sea surface

99 temperatures for simulating Hurricane Isabel (2003; Warner et al., 2010); effects of

100 waves to produce more accurate atmosphere and ocean dynamics during Nor'Ida (2009;

101 Olabarrieta, et al., 2012); more accurate intensity predictions for Hurricane Ivan (2004;

102 Zambon et al., 2014a); lack of significant impact on hurricane dynamics for Hurricane

103 Sandy (2012; Zambon et al., 2014b); and air-sea exchanges during extratropical cyclones

104 (Nelson et al., 2014) and coastal storm events (Renault et al., 2012).

105 Although numerical simulations of large-scale storm events have advanced in

106 recent years, predictions of sediment transport and geomorphic change are still

107 challenging. A common agreement is the need to use coupled modeling systems that can

108 communicate dynamic changes between all components of the modeling system during

109 the simulation, such as breaching of barrier islands and wave-current interactions at tidal

110 inlets. These processes can modify water exchange between the open-ocean to back-

111 barrier bays to enhance flooding hazards, and can exchange sediment between the

112 nearshore and inner continental shelf (Olabarrieta et al., 2011; de Vet, 2014).

113 Additionally these modeling scenarios require oceanographic observations (waves, wind,

114 currents) to provide ground truth of model predictions and require geologic information

115 to provide baseline data for the composition of the bottom substrate, sediment grain size,

116 seabed roughness, sediment availability, and coastal ocean topography.

117 In response to Hurricane Sandy, the U.S. Geological Survey (USGS) is leading a

118 multi-faceted mapping and research program designed to guide recovery and restoration

119 efforts (Buxton et al., 2013). Components of the program link coastal processes to

120 vulnerability, including how to quantify offshore sand resources suitable for recovery

121 efforts, establish linkages between nearshore geology, ocean processes, and island

122 response; and develop models that predict the coastal response to oceanographic forcing,

123 assess vulnerability, and predict barrier island evolution. Fire Island, NY, a barrier island

124 along southern Long Island (Fig. 1), and the adjacent inner continental shelf has been a 
125 primary focus of the USGS Hurricane Sandy response

126 (http://woodshole.er.usgs.gov/project-pages/coastal_change/study-sites/fire-island.html).

127 The USGS has long been involved in research in the New York inner-continental shelf

128 starting in 1996 with the objectives of evaluating the influence of the regional geologic

129 framework on coastal evolution, and formulating a conceptual model of sediment flux in

130 the coastal ocean (Schwab et al., 2000, 2013). In May of 2011, the USGS conducted a

131 high-resolution marine geophysical survey of the lower shoreface and inner continental

132 shelf offshore of Fire Island using interferometric sonar and seismic-reflection techniques

133 (Schwab et al., 2014b). Ultimately, this survey served to document conditions on the Fire

134 Island inner continental shelf approximately prior to the passage of Hurricane Sandy.

135 The USGS conducted additional surveys in 2014 to document post-storm conditions,

136 initially in January and February, in cooperation with the U.S. Army Corps of Engineers

137 (USACE), to re-survey the 2011 study area using a high-resolution multibeam

138 echosounder, and finally in October, to focus on a series of shoreface-attached sand

139 ridges offshore of western Fire Island using a high-resolution seismic-reflection profiler

140 (Schwab et al., 2015). The objectives of the post-storm surveys were to determine the

141 impact of Hurricane Sandy on the inner continental shelf morphology and modern

142 sediment distribution, and broaden the baseline geospatial framework for sediment

143 transport and coastal change model development. These post-Sandy surveys in 2014 also

144 included impacts from all other events from 2011-2014, including Hurricane Irene in

1452011.

146 The research presented here is part of this larger effort to better understand the

147 physical processes controlling coastal change during large storm events and to further the

148 understanding of storm-driven sediment flux on the inner continental shelf during

149 Hurricane Sandy. In this manuscript we focus on the applications of a coupled three-

150 dimensional deterministic numerical modeling system to simulate the oceanographic and

151 geologic changes during Hurricane Sandy, with results compared to oceanographic and

152 geologic data, encompassing the US east coast but focusing on the region south of Fire

153 Island, NY.

154

155 2. Geologic setting 
The US East coast is an open coastline characterized mostly by the rocky coast of

157 the Gulf of Maine (GoM) and sandy shores lined with barrier islands predominately in

158 the Mid Atlantic Bight (MAB) and South Atlantic Bight (SAB) (Figure 1). The

159 continental shelf along the coast varies in width. In the SAB it ranges from $5-120 \mathrm{~km}$ in

160 width with an average depth of about 50m, and in the MAB from 100-200 km width and

161 an average depth of 100-200 m (solid line Figure 1). Sediment distribution varies locally,

162 but is typically composed of coarse sand, sand, and regions of silt and clay in the SAB

163 and MAB, with increasing content of sandy clay and silty clay in the central region of the

164 GoM (Poppe et al., 2014).

165 The principal study area, the inner continental shelf and southern coastal region

166 along Long Island, New York, consists of reworked glacial outwash associated with the

167 Wisconsinan Laurentide glacial advance (Stone and Borns, 1986) and includes shallow

168 back-barrier bays, marshes, and low relief, sandy barrier islands (Leatherman, 1985).

169 Located within this barrier-island system is Fire Island, a 0.5-km-wide, 50-km-long

170 barrier island bound by two tidal inlets managed as navigation channels, Moriches Inlet

171 to the east and Fire Island Inlet to the west (Figure 2). A more thorough review of the

172 regional geologic framework and coastal evolution of the Fire Island study area,

173 including major inner continental shelf sedimentary sequences, sediment distribution, and

174 shelf morphology, is presented in Schwab et al. (2013, 2014b), and briefly summarized

175 below.

176 Pleistocene glaciofluvial outwash deposited during the Middle and Late

177 Wisconsinan glacial maximum compose the bulk of the sedimentary section above the

178 Cretaceous-age coastal plain strata (Williams, 1976). The strata are exposed at the

179 seafloor over much of the study area east of Watch Hill (Figure 2) and in the troughs

180 between the modern sand ridges west of Watch Hill. The strata is also covered by a

181 veneer $(<20 \mathrm{~cm}$ ) of modern sediment (Schwab et al., 2014b). The Pleistocene outwash

182 deposit is composed of poorly to very poorly sorted, medium-grained sand to gravel

183 (Schwab et al., 2000). The upper surface of the outwash is incised by fluvial

184 paleochannels that are filled with a transgressive sequence composed of reworked

185 outwash and, in places, caps of lower Holocene muddy estuarine sediment (Schwab et al.,

186 2000). East of Watch Hill geophysical data show numerous high-backscatter, <2 m deep 
187 depressions oriented $\sim 60^{\circ}-70^{\circ}$ to the shoreline that are interpreted to be sorted bedforms 188 (Figure 2). Schwab et al. (2013) interpreted the relatively high-backscatter base and eastward-facing flanks of the sorted bedform troughs to be indicative of continued

190 erosion of the seabed by oceanographic processes and net westward transport direction of 191 reworked sediment.

192 The eroded southeastern margin of a relatively young Pleistocene outwash lobe 193 offshore of central Fire Island is morphologically expressed as a submerged headland.

194 The southeast flank of this headland is in water depths from 18 to $20 \mathrm{~m}$ and is identified 195 as a high-backscatter gravelly lag deposit (Figure 2) that is thought to originate from 196 erosion of the young lobe during marine transgression. The lag deposit is suggested to 197 represent the seaward extent of the original lobe prior to marine transgression (Schwab et 198 al., 2014b). Schwab et al. (2013) inferred that erosion of this headland yielded an 199 abundant volume of very fine to medium grained sand, a primary source of sediment for 200 the development of the shoreface-connected sand ridges offshore of western Fire Island. 201 The modern sand deposits on the inner continental shelf south of Fire Island are 202 discontinuous and of variable thickness, and are composed of fine- to medium-grained, 203 moderately to well-sorted sand and are derived through erosion of older sedimentary 204 deposits exposed at the seafloor as marine transgression continues (Figure 3; Schwab et 205 al., 2000; 2014b). West of Watch Hill, the modern sedimentary deposit forms a series of 206 sedimentary structures referred to as shoreface-connected sand ridges (SFCRs) (Duane et 207 al., 1972; Schwab et al., 2014b). Similar sand ridges have been described in numerous 208 investigations of the North American inner continental shelf where they have seafloor 209 expressions ranging from $\sim 1$ to $10 \mathrm{~m}$, become more asymmetric with increasing water 210 depth, and their longitudinal axes are typically oriented $\sim 10^{\circ}-50^{\circ}$ relative to the 211 shoreline, matching the predominant storm wave approach direction and open into the 212 flow direction of the dominant alongshore current (Duane et al., 1972; McKinney et al. 213 1974; Swift and Freeland, 1978; Figueiredo et al., 1981; Swift and Field, 1981;

214 Stubblefield et al., 1984). The similarity in characteristics suggests a common set of 215 processes is responsible for the origin and maintenance of these sedimentary structures. 216 These ridges offshore of Fire Island vary in size and configuration but are, in general, on 217 the order of $10 \mathrm{~km}$ in length, have a crest to trough relief on the order of $6 \mathrm{~m}$, spaced 
218 about $3 \mathrm{~km}$ apart, and oriented obliquely from the coastline on average about 30 degrees

219 clockwise (Figure 3). Comparison of the sand ridge morphology with the morphology of

220 the underlying Holocene marine transgressive surface (stratigraphic unconformity

221 separating the modern sand deposit from the underlying Pleistocene deposit; a time-

222 transgressive erosional surface formed by rising sea level) and backscatter variations over

223 the ridges were interpreted to indicate that these ridges have moved westward since

224 formation (Schwab et al, 2014b).

225 Pre- and post-Hurricane Sandy maps of modern sediment thickness on the inner

226 continental shelf offshore of Fire Island were determined by comparing isopachs

227 produced from interpretations of the 2011 and 2014 seismic-reflection data (Figure 3B,

228 C). Sediment thicknesses were computed by converting along-track, two-way travel times

229 between the seafloor and the Holocene transgressive unconformity horizon to a thickness,

230 assuming an internal seismic velocity of 1,500 m/s (Schwab et al., 2014a). In general, the

231 isopachs of modern sediment vary from a thin veneer to almost $6 \mathrm{~m}$ thick to comprise the

232 morphology of the SFCR. There is also a relatively thick modern sediment deposit close

233 to the coast near the western limit of the study area (Figure 3B). This deposit is the lower

234 shoreface; i.e., the toe of the modern beach platform (Schwab et al., 2013, 2014b).

\section{Numerical Modeling}

237 To investigate the storm dynamic processes we utilize the COAWST numerical

238 modeling system that incorporates ocean circulation, surface waves, and sediment

239 transport components (Warner et al., 2010). Other capabilities, including an atmospheric

240 model, are available in this coupled system and have been used to investigate Hurricane

241 Sandy atmosphere - ocean dynamics (Zambon et al., 2014). However, for this series of

242 applications it was chosen to utilize a set of atmospheric surface forcings (described

243 below) and run the other model components to focus on the oceanographic and wave

244 response during the storm. For the oceanographic circulation we use the Regional Ocean

245 Modeling System (ROMS), a three-dimensional, free-surface, topography-following

246 numerical model, which solves finite difference approximations of Reynolds Averaged

247 Navier Stokes (RANS) equations using hydrostatic and Boussinesq approximations with

248 a split-explicit time stepping algorithm (Shchepetkin and McWilliams, 2005; Haidvogel 
249 et al., 2008; Shchepetkin and McWilliams, 2009). ROMS includes options for various

250 model components such as different advection schemes (second, third and fourth order),

251 turbulence closure models (e.g., Generic Length Scale mixing, Mellor-Yamada, Brunt-

252 Väisälä frequency mixing, user provided analytical expressions, K-profile

253 parameterization), and several options for boundary conditions. For surface waves, the

254 model utilizes the Simulating Waves Nearshore (SWAN), a spectral wave model that

255 solves for the transport of wave action density and includes source terms from wind and

256 sink terms to include wave energy dissipation due to whitecapping, breaking, and bottom

257 friction (Booij et al., 1999). The sediment routines are from the USGS Community

258 Sediment Modeling Project (Warner et al., 2008) and include many capabilities such as

259 suspended load, bed load, cohesive and non-cohesive, and multiple sediment classes.

260 The numerical simulations were performed on a coupled, triple-nested grid

261 configuration. The outermost grid covers the US East Coast and Gulf of Mexico with a

262 spatial resolution on the order of $5 \mathrm{~km}$ (Figure 4A). This US East grid (USE) is typically

263 large enough to encompass the full scale of a hurricane or extra-tropical storm system.

264 Nested within the USE grid by a scale factor of 7 is the New York Bight grid (NYB) with

265 a spatial resolution on the order of $700 \mathrm{~m}$ (Figure 4B). This scale was selected to capture

266 the landfall of Hurricane Sandy. The third grid was further nested with a scale factor of 7

267 to cover the inner continental shelf (SHF) and extent of Fire Island study area (Figure 4C)

268 and has a spatial resolution on the order of $100 \mathrm{~m}$. All three grids were simulated

269 concurrently as a nested-coupled application: two-way ocean refinement and one-way

270 wave refinement with fully coupled exchanges between all three grids for the fields of

271 water levels, currents, bathymetry, and bottom roughness from the ocean to the wave

272 model, and wave dissipation, height, length, direction, surface and bottom periods, and

273 bottom orbital velocities from the wave to the ocean model. The relevant ocean physics

274 that include waves are surface enhanced roughness due to the waves from Taylor and

275 Yelland (2001), surface enhanced flux of turbulent kinetic energy due to wave breaking

276 based on Craig and Banner (1994) with an increased roughness dependent on the sea state

277 (Carniel et al., 2009), wave effects on currents as described in Kumar et al. (2012) based

278 on the approach from Uchiyama et al. (2010), and the enhanced bottom roughness due to

279 waves from Madsen (1994). The wave dynamics that are enhanced from coupling to the 
ocean model include the effects of varying bottom roughness, changes in water level, and

281 effects from near-surface currents based on Kirby and Chen (1989).

282 The larger USE grid is run as part of a coupled daily forecast that has been

283 ongoing for the past several years (Warner et al., 2010). For the numerical simulations as

284 part of this specific study, the initial conditions for all 3 grids were obtained from that

285 forecast database, and then the triple nested configuration was simulated from October 25

286 to November 5, 2012. This time period includes a duration when the Hurricane was just

287 starting to impact the southern coast of the US and lasting to a time after landfall. Model

288 results from the forecast on the larger grid will also be presented on days before and after

289 the triple nested configuration to show continuity of output.

290 For the triple nested configuration, the ocean model was forced with atmospheric

291 data of winds, pressure, air temperature, relative humidity, precipitation, and heat fluxes

292 from combined data sets of NAM and NARR (http://nomads.ncdc.noaa.gov/data.php).

293 Lateral open boundaries were prescribed with velocity, salt, and temperature from

294 HYCOM (http://tds.hycom.org/thredds/dodsC/GLBa0.08/expt_90.9), and during the

295 simulation the model tracer fields of salinity and temperature were nudged to HYCOM

296 data on a four-day time scale. The wave model was simulated with the same wind forcing

297 as the ocean and was also prescribed with parametric wave data along the USE grid open

298 boundary from WaveWatch III (ftp://polar.ncep.noaa.gov/pub/history/waves/). In

299 practicality, due to the magnitude of this storm and the extent of the USE grid, the lateral

300 wave boundaries did not have significant influence on the model results.

$301 \quad$ For the USE grid, the sediment texture was initialized from the USGS national

302 sediment database (Poppe et al., 2014) and includes six grain-size classes that are

303 described in Table 1. This distribution has been numerically evolving for the past several

304 years as part of a forecast system and results presented here include that evolution. The

305 NYB and SHF grids were also initialized with the same six classes. However, because

306 adequate spatial distribution is not available for all regions of these refined grids, they

307 were initialized with a uniform sediment distribution composed of the same six classes.

308 Sensitivity tests were performed to evaluate initial sediment distributions and sensitivity

309 to erosion rate magnitudes. Results indicate that spatial patterns remained consistent and

310 were not sensitive to the initial sediment field. However the magnitude of bed elevation 
311 change did depend on initial conditions and more significantly to erosion rate values.

312 These rates were based on comparisons to other modeling scenarios and local (non-

313 hurricane) storm observations. Ultimately, the spatial patterns remained the same, only

314 the magnitude of change varied.

315

Table 1. USE grid sediment types

\begin{tabular}{|l|l|l|l|l|l|}
\hline $\begin{array}{c}\text { mean grain } \\
\text { size } \\
(\mathrm{mm})\end{array}$ & \multicolumn{1}{|c|}{$\begin{array}{c}\text { density } \\
\left(\mathrm{kg} \mathrm{m}^{-3}\right)\end{array}$} & $\begin{array}{c}\text { settling } \\
\text { velocity } \\
\left(\mathrm{mm} \mathrm{s}^{-1}\right)\end{array}$ & $\begin{array}{c}\text { erosion rate } \\
\left(\mathrm{kg} \mathrm{m}^{-2} \mathrm{~s}^{-1}\right)\end{array}$ & $\begin{array}{c}\text { critical } \\
\text { erosion } \\
\text { stress }(\mathrm{Pa})\end{array}$ & $\begin{array}{c}\text { bed porosity } \\
(-)\end{array}$ \\
\hline 1.0 & 2650 & 140.0 & $1 \mathrm{E}-3$ & 0.53 & 0.7 \\
\hline 0.5 & 2650 & 57.0 & $1 \mathrm{E}-3$ & 0.27 & 0.7 \\
\hline 0.25 & 2650 & 27.0 & $1 \mathrm{E}-3$ & 0.19 & 0.7 \\
\hline 0.125 & 2650 & 8.7 & $1 \mathrm{E}-3$ & 0.14 & 0.7 \\
\hline 0.0625 & 2650 & 2.4 & $1 \mathrm{E}-3$ & 0.09 & 0.7 \\
\hline 0.03125 & 2650 & 0.62 & $1 \mathrm{E}-3$ & 0.06 & 0.7 \\
\hline
\end{tabular}

318 The model grids were time stepped with 180, 30, and 15 seconds (for USE, NYB, and

319 SHF grids) for the ocean, and 300, 60, and 30 seconds for the wave model. During the

320 few days of landfall simulation, the ocean time steps were reduced to 45,15 , and 5

321 seconds because the ocean currents became considerably stronger and the explicit time

322 stepping stability criteria limited the time steps.

324 4. Results

325 In order to assess the impact of different physical processes, several numerical

326 simulations were performed. Run 1 was a realization that included full exchanges

327 between the ocean and wave models, as described previously. Run 2 was the same as Run

328 1, but did not allow the effects of waves on currents (no vortex force or Stokes transport),

329 and did not impose any surface winds or atmospheric pressure changes on the ocean, but

330 was still forced with tides, baroclinicity, and Coriolis. Differences between Run 1 and

331 Run 2 will identify the increase of oceanic water levels (surge) due to the storm winds

332 and atmospheric pressure. 


\subsection{Water levels}

335 In addition to the effect of tides, changes in water levels along the inner

336 continental shelf and coast occur due to wind-driven flows, Stokes transport, and the

337 lower atmospheric pressure. As the storm tracked north, water levels increased along the

338 entire US East Coast, typically for at least 8 tidal cycles over the storm event. Increased

339 surge occurred along the storm track itself, but predominately to the west and north of the

340 track, with the greatest impact in the NYB. Figure 5 shows time series of water levels

341 from five locations along the coast (identified in Figure 1) that were observed (blue

342 lines), and predicted from Run 1 (full storm dynamics, red lines) and Run 2 (reduced

343 forcing on ocean, black lines). At Charleston, SC, there was a slight increase in water

344 levels with a high tide that reached approximately $1.2 \mathrm{~m}$ above mean sea level (MSL)

345 near October 28 at 1200 UTC. This was only a surge of approximately $0.40 \mathrm{~m}$ greater

346 than a tide that would have occurred without the storm. Further north at Lewes, DE, the

347 maximum water level reached approximately $1.9 \mathrm{~m}$ above MSL near October 29 at 1200

348 UTC, which was a greater surge of approximately $1.2 \mathrm{~m}$ over the normal tide level. Peaks

349 in water level at Sandy Hook, NJ, the Battery, NY, and Woods Hole, MA all occurred

350 near the storm landfall on October 30, 0000 UTC, with maximum water levels of nearly

$3513.2 \mathrm{~m}$ above MSL at Sandy Hook and the Battery, and $1.7 \mathrm{~m}$ above MSL at Woods Hole,

352 consistent with observations. These water levels were all greater than the tide-only

353 scenario, with maximum modeled storm surge on the order of $2.6 \mathrm{~m}$ at Sandy Hook and

354 the Battery, and 1.3m at Woods Hole.

355 The maximum predicted surge for the entire US East Coast and Gulf of Mexico

356 was computed by taking the difference in water of the full simulation with all the forcings

357 (Run 1) minus the simulation with mainly tidal forcing (Run 2). This allows visualization

358 of the distribution of the maximum surge that occurred during the storm (Figure 1).

359 Along the hurricane track in the open ocean, the surge was on the order of $0.75 \mathrm{~m}$. This is

360 consistent with a change in water level height due to a drop of pressure from about

$3611025 \mathrm{mb}$ of typical atmospheric pressure to $945 \mathrm{mb}$ in the eye of the hurricane. This

362 change in pressure results in an increase of sea level that can be computed from the

363 hydrostatic balance of $\Delta \mathrm{h}=\Delta \mathrm{P} /(\rho \mathrm{g})=(1025-945 \mathrm{mb}) /\left(1025 \mathrm{~Pa} * 9.81 \mathrm{~ms}^{-2}\right) \sim 0.80 \mathrm{~m}$, 
364 where $\mathrm{h}$ is water level difference, $\mathrm{P}$ is pressure, $\rho$ is density, and $\mathrm{g}$ is gravitational

365 acceleration. Along the SAB coastline, the maximum surge is also on the order of $0.70 \mathrm{~m}$

366 that extended across the shelf width (100m isobath, dotted line on Figure 1). In the MAB

367 the surge was the greatest in NY Bight region, reaching over $2.5 \mathrm{~m}$. This location was in

368 the right front quadrant of the storm and the shape of the coastline allowed water to be

369 funneled into this region and the water elevation amplified. In Massachusetts Bay, surge

370 also reached over $1 \mathrm{~m}$ along the east coast due to the wind field extending almost 1000

371 miles wide just prior to landfall (Schubert et al., 2015). Increased water levels are shown

372 to extend as far north as the Bay of Fundy.

373 The timing of the maximum surge (Figure 1B) is consistent with the translation of

374 the hurricane center. Maximum surge occurred along the SAB coast near October 28

375 (Figure 1B). At that time the hurricane eye was southeast of the SAB. Similarly, the

376 maximum surge along the coast of the Outer Banks of NC occurred near October 29 at

3771200 UTC when the storm was offshore of Cape Hatteras. The maximum surge in the

378 NYB occurred at landfall on October 29 at 2300 UTC. Along the outer shelf offshore of

379 the MAB-SAB there are locations that show maximum surge after landfall, occurring

380 when winds were blowing offshore and during relaxation of the inner shelf setup.

\subsection{Waves}

383 Hurricane Sandy produced large waves along the entire US East Coast and in the

384 GoM. Comparisons between observed and modeled significant wave heights (Figure 6)

385 show a strong agreement, with the storm having a distinctive peak in wave height. At the

386 entrance to the Chesapeake Bay (NDBC 44099; water depth 18m) wave heights reached

387 up to $5 \mathrm{~m}$ with a peak on October 29 at 0200 UTC. Coastal wave heights increased

388 northward reaching up to $7 \mathrm{~m}$ at the Delaware Bay entrance (NDBC 44009; water depth

$389 \sim 30 \mathrm{~m}$ ), and up to 10m offshore south of Long Island (NDBC 44065; water depth 25m)

390 and south of Block Island (NDBC 44097; water depth 48m). These buoys were

391 positioned in the northeast quadrant of the storm where wave heights are amplified due to

392 increased surface ocean stress produced by winds blowing in the direction of storm

393 propagation. 
The maximum simulated wave heights that occurred at any instance in time

395 during the Hurricane are shown in Figure 7A. The storm created increased wave heights

396 along the entire US East Coast, with minimal impact in the Gulf of Mexico. While the

397 Hurricane was offshore in the SAB, regions of increased wave height developed offshore

398 of the shelf break (offshore of the $100 \mathrm{~m}$ contour, Fig 7A) reaching over 13m. These

399 extreme values occurred because the waves were travelling in opposition to the Gulf

400 Stream and therefore the relative wave speed was reduced and created current-induced

401 shoaling of the waves. Landward of the $100 \mathrm{~m}$ isobath, the waves were considerably

402 smaller due to wave energy loss from bottom friction, however, heights still reached up to

$4035 \mathrm{~m}$ along the inner continental shelf. As the storm translates, the maximum waves are

404 typically in the right front quadrant (Fan et al, 2009). During Hurricane Sandy, predicted

405 maximum wave heights did occur in the right front quadrant, especially when the storm

406 turned towards the northwest on October 29 at 0600 UTC. Maximum coastal waves

407 occurred where the storm made landfall on the right front quadrant on October 30 at 0000

408 UTC, and offshore the wave heights reached upwards of $10 \mathrm{~m}$ in a band that stretched

409 1000km wide.

410 Generally along a hurricane storm track, wave height maximums precede passage

411 of the eye of the storm, due to reduction of wind stress in the inner eye and lower relative

412 wind speeds on the back side of the storm. However, model results suggest that for Sandy

413 the maximum heights occurred along the track after the eye had passed (Figure 7B). This

414 is most likely because the storm had multiple peaks of intensity. On October 25 at 0500

415 UTC the storm had a low pressure of $955 \mathrm{mb}$, but then gradually weakened until October

41626 at 1800 UTC to $970 \mathrm{mb}$. After that the storm re-intensified until early on October 29

417 and reached a secondary minimum of $940 \mathrm{mb}$ (Blake et al., 2013). This cycling of

418 intensity can cause wave heights produced in the rear quadrants of a storm during later

419 periods of higher intensity to exceed those produced in the leading quadrants during

420 earlier periods of lower intensity.

421 Model results suggest that maximum water level surge (Figure 1) preceded

422 maximum wave heights (Figure 7) along the track of Hurricane Sandy. This is because

423 the water level displacement at the eye is predominately driven by the reduction in

424 atmospheric pressure which occurs most when the eye is at that location. The wave 
425 heights are driven by the winds which are typically stronger on the leading front of the

426 storm, but for this particular storm which had multiple intensity peaks, the maximum

427 wave heights along the track occurred after the storm eye passed. This unusual

428 relationship is probably related to cycling intensity during the storm. In general during

429 Sandy the timing of the largest wave heights occurred before the highest water levels on

430 the inner continental shelf of the SAB and in the upper Chesapeake and upper Delaware

431 Bays, on the order of 8-15 hours. On the inner continental shelf offshore of the

432 Chesapeake Bay mouth the highest water levels occurred before the maximum wave

433 heights on the order of 8-10 hours. At the location of landfall, the highest water levels

434 occurred before the maximum wave heights on the order of just a few hours.

\subsection{Surface Currents}

$437 \quad$ Ocean surface currents along the US East Coast are driven primarily by tides and 438 surface wind stress. Surface tidal currents in the SAB and MAB can reach up to $0.5 \mathrm{~ms}^{-1}$ 439 and typical wind-driven currents can reach up to $1 \mathrm{~ms}^{-1}$ (Sullivan et al., 2006; Armstrong 440 et al., 2011; Armstrong et al., 2014). Coastal surface currents are continuously derived, 441 maintained, and distributed by the High-Frequency Radar National Network (HFRnet; 442 http://cordc.ucsd.edu/projects/mapping/). Data was obtained for the US East and Gulf 443 Coast, $6 \mathrm{~km}$ resolution, hourly real time vectors data set as a combined source from a 444 distributed network of shore-based high-frequency radar systems (HFRADAR). Data is 445 typically available continuously along the US East Coast from Cape Hatteras north to 446 Cape Cod, out to a distance of approximately $350 \mathrm{~km}$. But as Sandy approached data 447 availability became limited in many areas. Modeled currents are compared to the 448 HFRADAR measurements.

449 During Hurricane Sandy the maximum simulated surface stress exceeded $6 \mathrm{~Pa}$ 450 offshore of the MAB coastline. On October 29 at 0000 UTC the hurricane was centered 451 approximately $500 \mathrm{~km}$ offshore east of Cape Hatteras (latitude 33.9, longitude -71.0). The 452 wind stress drove an enhanced surface current towards the southwest in the MAB and 453 north into the Gulf of Maine (Figure 8A). Modeled surface currents (black arrows) show 454 an onshore transport and bifurcation of the currents south of Cape Cod that lead west 455 along the southern coast of Long Island and north into the Gulf of Maine. Winds along 
456 the coast were predominately towards the southwest and driving a surface current to the 457 west (south of Long Island) and towards the southwest along the coasts of NJ, DE, MD,

458 VA, and NC. Surface currents from the COAWST model also follow the coast and agree 459 with the HFRADAR observations, both in direction and magnitude, with speeds on the 460 order of $0.5 \mathrm{~ms}^{-1}$. The modeled currents show the Gulf Stream meandering towards the 461 northeast with an eddy near the eastern boundary of Figure 8A. Also the currents split 462 south of Cape Cod to show flow into the Gulf of Maine that match the HFRADAR 463 observations.

464 As the Hurricane approached the coastline on October 29 at 1800 UTC, the eye 465 was centered in the MAB near -73 longitude and 38 latitude and wind speeds intensified 466 along the coast (Figure 8B). Coastal surface winds reached near $20 \mathrm{~ms}^{-1}$ and the offshore 467 wind speed maximum was over $40 \mathrm{~ms}^{-1}$. South of Long Island winds were still westerly, 468 but farther south, winds along the coast shifted offshore between Delaware and Cape

469 Hatteras. The coastal surface currents increased to over $2 \mathrm{~ms}^{-1}$ along the coast offshore of 470 New Jersey south to North Carolina. The strength and direction of the modeled currents 471 are in agreement with the HFRADAR measurements.

\subsection{Bottom Currents and Stress}

$474 \quad$ Modeled bottom currents on the inner continental shelf were typically smaller in 475 magnitude than the surface currents, reaching no higher than $0.5 \mathrm{~ms}^{-1}$. These bottom 476 currents were of sufficient magnitude in combination with waves to produce maximum 477 bottom stress during Hurricane Sandy over 8 Pa (Figure 9A). In the SAB, bottom stress 478 peaks occurred on the east Florida shelf and across Frying Pan, Cape Lookout, and 479 Diamond Shoals offshore of the Carolinas Capes. In the MAB, bottom stresses were 480 higher and more prevalent over almost the entire continental shelf, with maximums in the 481 right front of the landfall, along the southern edge of Long Island, and offshore of Cape 482 Cod on Nantucket Shoals and Georges Bank.

483 Focusing on the NYB, the higher-resolution bathymetry in the NYB grid allows 484 for a more detailed representation of the seafloor topography and hence the stresses 485 (Figure 9B). Along the coast of New Jersey and the southern edge of Long Island the 486 stresses reach as high as 12 Pa. A zone of reduced stress is evident along the Hudson 
487 Shelf Valley, with minimums in the valley resulting from depths exceeding the limits of

488 wave-induced stresses. Further refinement (Figure 9B) of the SHF grid is overlaid on the

489 NYB grid and allows details of changing stress over the SFCRs along southern Long

490 Island. The stresses vary from up to $12 \mathrm{PA}$ at the ridge crests to almost $7 \mathrm{~Pa}$ in the

491 troughs. This variation will produce gradients in sediment fluxes causing seafloor

492 changes.

493

494 5. Discussion

$495 \quad 5.1$ Sediment Transport

$496 \quad$ Sediment transport occurred in both bedload and suspended load fractions during

497 Hurricane Sandy. For the simulation, the suspended load was several orders of magnitude

498 larger than the bedload. On the USE grid, the sea-floor sediments were composed of six

499 sediment fractions that were based on the initial distribution from the forecast (Table 1).

500 In the Gulf of Maine (Figure 10A), the mean bed sediment grain size is coarser over

501 Nantucket Shoals and George's Bank and is on the order of $1 \mathrm{~mm}$, with a finer grain size

502 in the central region of less than $0.1 \mathrm{~mm}$. The net suspended sediment fluxes during the

503 storm show a counter-clockwise rotation in the Gulf of Maine. Flow entered from south

504 of Nova Scotia and traveled northward toward the coast of Maine. A coastal current to

505 the south driven by winds moved sediment southwest along the outer arm of Cape Cod,

506 and south along Nantucket Shoals. Offshore, flux around Georges Bank was clockwise

507 with sediment entering GoM to its west and exiting to its east. The largest sediment flux

508 was westward south of Cape Cod, where high bottom stresses (Figure 9) occurred across

509 a relatively shallow region composed of fine-grained, readily erodible sediment.

510 In the MAB (Figure 10B) the net suspended sediment flux is to the west and south

511 along the coast. South of Long Island, the sediment is driven west along the coast until it

512 encounters the Hudson Shelf Valley, where the sediment flux is driven southward, down

513 valley and offshore. This net down-valley flux has been observed previously during large

514 storm events (Harris et al., 2003; Lentz et al., 2014). Immediately to the southwest of the

515 canyon is a subtle, low relief zone composed of coarser material over which the net flux

516 is slightly offshore and towards the southwest. Along the coast north of the Delaware Bay 
517 entrance south to Cape Hatteras the fluxes change in magnitude due to spatial gradients in

518 grain size, and increase towards the Cape as the shelf narrows and the flows increase.

\subsection{Seafloor elevation changes}

$521 \quad$ The predicted gradients in sediment fluxes result in changes to the sediment

522 distribution and seabed elevation. These predicted changes in bed thickness vary along

523 the coast, but typically range from $+/-0.4 \mathrm{~m}$ (Figure 11A). At the scale of the USE model

524 grid (5 km grid spacing), the resolved seafloor variations are at the same scale or greater.

525 This means that features such as the width of the inner continental shelf are well

526 simulated. As a finer grid resolves more seafloor features, predicted changes over those

527 features are, in turn, better resolved. In the Gulf of Maine, sediment eroded at the

528 southern tip of Nova Scotia was transported and deposited approximately $25 \mathrm{~km}$ to the

529 north. Similar erosion was predicted south of Penobscot Bay, with that material

530 transported southwest and deposited along the coast. One of the larger regions of

531 predicted change is south of Cape Cod, at a location with a smaller grain size, where

532 erosion on the order of $0.30 \mathrm{~m}$ resulted in significant transport and deposition to the west.

533 In the MAB, alternating patterns of erosion and accretion were predicted along

534 the shelf (Figure 11A.) Deposition was indicated within the Hudson Shelf Valley, while

535 erosion occurred across its flanks. At Cape Hatteras, intense erosion on the narrow inner-

536 continental shelf was accompanied by deposition offshore of Diamond Shoals. These

537 patterns in the MAB are very similar to those simulated by Miles et al. (2015). The model

538 results presented here have a larger magnitude of change (about a factor of 10 from +/-

$5394 \mathrm{~cm}$ to $+/-40 \mathrm{~cm}$ ), most likely due to increased erosion rates set in the model simulation

540 based on local observations. In the SAB, the major changes were predicted at Cape

541 Lookout and Cape Fear, where sediments were eroded from the shoal crests and

542 deposited to the southwest.

$543 \quad$ Higher-resolution predictions generated using the NYB grid (Figure 11B), suggest

544 a region of erosion offshore of central Fire Island (corresponding to the submerged

545 headland), as well as alternating patterns of erosion and accretion in the vicinity of the

546 SFCRs, and other areas of alternating erosion and accretion patterns along the $\mathrm{NJ}$ and

547 Long Island coasts. These results also suggest at least $25 \mathrm{~cm}$ of deposition in the along 
548 the axis of the Hudson Shelf Valley, consistent with previous findings that suggest down 549 valley driven by westward winds (Lentz, et al., 2014).

$550 \quad$ Numerical results from the SHF grid provide the highest-resolution prediction of 551 seafloor changes along Fire Island (Figure 12A). Model results show erosion dominated 552 near the coast of eastern Fire Island, with that material being transported to the west and 553 slightly offshore during this event. Modeled results along the eastern region also show 554 alternating zones of erosion and accretion (Figure 12A), and these linear accretionary 555 zones that extend seaward and are coincident with inner shelf sorted bedforms (Figure 2).

556 Offshore of the center of the island near the grid boundary is the modeled region of 557 greatest erosion (Figure 12A) that is consistent with the location of maximum bottom 558 stress. This location is coincident with the high-backscatter gravel area associated with 559 the eroded remains of a buried Pleistocene headland (Figure 2). It is unknown what actual 560 stresses are needed to liberate sediment from this location. However, the region is 561 overlain with a veneer of sediment that was certainly available to be eroded from this 562 location. Along the central and western segments of the island, in the area of the SFCRs, 563 alternate patterns of erosion and accretion were indicated with erosion on ridge crests and 564 deposition on the lee flanks. The mean change of modeled bed elevation for the region in 565 the grid that is coincident with the geologic mapping (Figure $12 \mathrm{~A}$, black outlined area) is $566-0.03 \mathrm{~m}$.

567 The isopachs of surficial sediment thickness interpreted from the seismic568 reflection surveys in 2011 and 2014 are useful for evaluating the sea-floor elevation 569 changes predicted by the model along Fire Island. The difference between the 2011 and 5702014 isopach values was computed to yield a $50 \mathrm{~m} /$ pixel difference grid that illustrates 571 areal patterns of accretion and erosion over the three-year period within the area common 572 to the two surveys (Schwab et al., 2015; Figure 12C). In the vertical, a conservative 573 estimate of the vertical resolution limits of the subbottom profiling system is used and 574 differences less than $0.10 \mathrm{~m}$ (-0.10 to $0.10 \mathrm{~m})$ are removed when showing change in 575 sediment thickness.

576 The spatial patterns of modeled bed elevation change on the SHF grid closely 577 agree with the change in modern sediment thickness mapped from the 2011 and 2014 578 seismic-reflection data (Fig. 12B and 12C). The isopach difference grid indicates a 
579 general pattern consisting of erosion on the northeast-facing ridge flanks and crests of the 580 sand ridges, and deposition on their southwest ridge flanks and in the troughs between 581 them, indicating a net southwesterly migration of the shoreface-connected sand ridges. 582 Statistics computed on the difference grid suggest that the modern sediment volume 583 across the $\sim 81 \mathrm{~km}^{2}$ of common seafloor mapped in both surveys decreased by $2.8 \times 10^{6}$ $584 \mathrm{~m}^{3}$; a mean change in sediment thickness of $-0.03 \mathrm{~m}$. Results from the model are similar 585 in pattern, but smaller in magnitude. This may be due to the observed difference being 586 from a 3-yr-long time period, but the model difference is from only simulating one large 587 storm event with assumptions of modeled erosion rates and spatial variations in grain 588 size.

Thus, the combined impacts of Hurricanes Irene (Aug 2011) and Sandy (Oct 591 eroded from the ridge crests and deposited on the western flanks or troughs. The 592 modeling scenarios simulated for this research focused on Hurricane Sandy, however the 593 impacts of Hurricane Irene are also inherently in the geophysical data comparisons.

594 However, analysis of the COAWST forecast modeling archive show that the modeled 595 impacts of Irene were significantly less than that of Hurricane Sandy, and identifies that 596 Hurricane Sandy was likely to be the dominant impact during this time period.

\section{Conclusions}

Hurricane Sandy was a severe storm that impacted the US east coast in October 2012, causing massive coastal impacts. Post-storm assessments identified subaerial changes to the coastal region. To identify subaqueous impacts, geophysical surveys from

604 seafloor from the storm. Numerical simulations were performed of the Hurricane using a 605 coupled numerical modeling system with grid refinement to resolve increasing spatial 606 resolutions along the US East Coast (5 km), New York Bight (700m), and offshore of 607 Fire Island, NY (100 m). Comparison of model to observations of water levels, waves, 608 and currents demonstrates strong skill of the model results and identifies peak locations 609 and times of maximum water levels, wave heights, and bottom stresses. Analysis of the 
610 simulated sediment changes shows alternating patterns of erosion and accretion along the

611 east coast, deposition in the Hudson Shelf Valley, and erosion along crests and deposition

612 in the troughs of SFCR offshore of Fire Island. Model results are consistent with the

613 spatial patterns and volumetric magnitudes of surficial sediment changes measured from

614 time series seismic-reflection surveys. Model forecast archived results support that the

615 majority of seafloor changes observed are related to the impact from Hurricane Sandy

616 with minor effects from Hurricane Irene.

617

\section{Acknowledgements}

619 This research was funded by the U.S. Geological Survey, Coastal and Marine

620 Geology Program, and conducted by the Coastal Change Processes Project. Additional

621 support was provided by the Hurricane Sandy Supplemental Funding. We acknowledge

622 and appreciate the contributions for USGS and anonymous reviewers.

623

\section{References}

625

Armstrong, B.N., Warner, J.C., Voulgaris, G., List, J.H., Thieler, E.R., Martini, M.M., Montgomery, E.T., (2011), Carolinas Coastal Change Processes Project Data Report for Observations near Diamond Shoals, NC from January-April 2009: U.S. Geological Survey Open-File Report 2011-1156, http://pubs.usgs.gov/of/2011/1156/.

Armstrong, B.N., Warner, J.C., List, J.H., Martini, M.M., Montgomery, E., Voulgaris, G., and Traykovski, P. (2014). Coastal Change Processes Project data report for observations near Fire Island, New York, January to April 2012: U.S. Geological Survey Open-File Report 2014-1159, http://pubs.usgs.gov/of/2014/1159.

Bender MA, Ginis I, Tuleya R, Thomas B, Marchok T (2007) The operational GFDL Coupled Hurricane-Ocean Prediction System and a summary of its performance. Mon Wea Rev 135: 650 3965-3989. doi:10.1175/2007MWR2032.1

Blake, E.S., Kimberlain, T.B., Berg, R.J., Cangialosi. J.P., and Beven II, J.L. (2013). Tropical Cyclone Report Hurricane Sandy (AL182012) 22 - 29 October 2012, National Hurricane Center, http://www.nhc.noaa.gov/data/tcr/AL182012_Sandy.pdf.

Booij, N., Ris, R.C., Holthuijsen, L.H., 1999. A third-generation wave model for coastal regions. Part I: Model description and validation. Journal of Geophysical Research 104 (C4), 7649-7666. 
Buxton, H.T., Andersen, M.E., Focazio, M.J., Haines, J.W., Hainly, R.A., Hippe, D.J., and Sugarbaker, L.J., 2013, Meeting the science needs of the Nation in the wake of Hurricane Sandy-A U.S. Geological Survey science plan for support of restoration and recovery: U.S. Geological Survey Circular 1390, 26 p., http://pubs.usgs.gov/circ/1390/.

Carniel, S., Warner, J.C., Chiggiato, J., Sclavo, M., 2009. Investigating the impact of surface wave breaking on modelling the trajectories of drifters in the Northern Adriatic Sea during a wind-storm event. Ocean Model. 30, 225-239.

Chen, S. Y. S., J. F. Price, W. Zhao, M. A. Donelan, and E. J. Walsh, 2007: The CBLAST-hurricane program and the next-generation fully coupled atmospherewave-ocean. Models for hurricane research and prediction. Bull. Amer. Meteor. Soc., 88, 311-317.

Craig, P.D., Banner, M.L., 1994. Modeling wave-enhanced turbulence in the ocean surface layer. J. Phys. Oceanogr. 24, 2546-2559.

Denny, J.F., Schwab, W.C., Baldwin, W.E., Barnhardt, W.A., Gayes, P.T., Morton, R.A., Warner, J.C., Driscoll, N.W., and Volgaris, G. (2013) Holocene sediment distribution on the inner continental shelf of northeastern South Carolina: implications for the regional sediment budget and long-term shoreline response. Continental Shelf Research 56, 56-70.

De Vet, P.L.M., Stive, M.J.F., Den Bieman, J.P., McCall, R.T., Talmon, A.M., Visser, P.J., and Yuan, J. (2014). Modelling sediment transport and morphology during overwash and breaching events, Master Thesis, Civil Engineering and Geosciences, Hydraulic Engineering Department, Delft University of Technology.

Duane, D.B., Field, M.E., Meisburger, E.P., Swift, D.J.P., and Williams, S.J. (1972) Linear shoals on the Atlantic inner shelf, Florida to Long Island, In: Swift, D.J.P., Duane, D.B., and Pilkey, O.H. (Eds.) Shelf Sediment Transport. Dowden, Hutchinson, and Ross, pp. 447-449.

Fan Y., Ginis, I., and Hara, T. (2009). The effect of wind-wave-current interaction on airsea momentum fluxes and ocean response in tropical cyclones. Journal of Physical Oceanography, 1019-1034, doi:10.1175/2008JPO4066.1.

Figueiredo, A.G., Swift, D.J.P., Stubblefield, W.L., and Clarke, T.L. (1981) Sand ridges on the inner Atlantic shelf of North America: morphometric comparisons with Huthnance stability model. Geo-Marine Letters 1, 187-191.

Goerss, J.S. (2006) Prediction of tropical cyclone track forecast error for Hurricanes Katrina, Rita, and Wilma. Preprints, 27th Conf. on Hurricanes and Tropical Meteorology, Monterey, CA, Amer Meteor Soc 11A.1. 
Goff, J.A., Flood, R.D., Austin, J.A., Schwab, W.C., Christiensen, B., Browne, C.M., Denny, J.F., and Baldwin, W.E. (2015) The impact of Hurricane Sandy on the shoreface and inner shelf of Fire Island, New York: large bedform migration but limited erosion. Continental Shelf Research 98, 13-25.

Haidvogel, D. B. , Arango, H.G., Budgell, W. P., Cornuelle, B. D., Curchitser, E., Di Lorenzo, E., Fennel, K., Geyer, W. R., Hermann, A. J., Lanerolle, L., Levin, J., McWilliams, J. C., Miller, A. J., Moore, A. M., Powell, T. M., Shchepetkin, A. F., Sherwood, C. R., Signell, R. P., Warner, J. C., Wilkin, J., 2008. Ocean forecasting in terrain-following coordinates: Formulation and skill assessment of the Regional Ocean Modeling System, Journal of Computational Physics. 227, 3595-3624.

Hapke, C.J., Brenner, O., Hehre, R., and Reynolds, B.J. (2013) Coastal change from Hurricane Sandy and the 2012-13 winter storm season — Fire Island, New York. U.S. Geological Survey Open-File Report 2013-1231, 37 p., http://pubs.usgs.gov/of/2013/1231/.

Harris, C. K., B. Butman, and P. Traykovski (2003), Winter-time circulation and sediment transport in the Hudson Shelf Valley, Cont. Shelf Res., 23, 801-820.

Kirby, J.T., Chen, T.-M., 1989. Surface waves on vertically sheared flows: approximate dispersion relations. J. Geophys. Res. 94, 1013-1027.

Kumar, N., Voulgaris, G., Warner, J.C., and M., Olabarrieta (2012). Implementation of a vortex force formalism in a coupled modeling system for inner-shelf and surfzone applications. Ocean Modelling, 47, 65-95.

Leatherman, S.P. (1985) Geomorphic and stratigraphic analysis of Fire Island, New York. Marine Geology 63, 173-195.

Lentz, S. J., B. Butman, and C. Harris (2014), The vertical structure of the circulation and dynamics in Hudson Shelf Valley, J. Geophys. Res. Oceans, 119, 3694-3713, doi:10.1002/2014JC009883.

Madsen, O. S. (1994) Spectral wave-current bottom boundary layer flows. Coastal Engineering 1994. Proceedings, 24th International Conference, Coastal Engineering Research Council / ASCE, 384-398.

Marks, F.D., and Shay, L.K. (1998) Landfalling tropical cyclones: Forecast problems and associated research opportunities. Bull Amer Meteor Soc 79:305-323.

McKinney, T.F., Stubblefield, W.L., and Swift, D.J.P. (1974) Large-scale current lineations on the central New Jersey shelf: investigations by side-scan sonar. Marine Geology 17 (2), 79-102. 
Miles, T., G. Seroka, J. Kohut, O. Schofield, and S. Glenn (2015), Glider observations and modeling of sediment transport in Hurricane Sandy, J. Geophys. Res. Oceans, 120, 1771-1791, doi:10.1002/2014JC010474.

Miselis, J.L., and McNinch, J.E. (2006) Calculating shoreline erosion potential using nearshore stratigraphy and sediment volume: Outer Banks, North Carolina. Journal of Geophysical Research 111, 1-15.

Nelson, J. He, R., and Warner, J.C., Bane, J. (2014). Air-Sea Interactions during Strong Winter Extratropical Storms, Ocean Dynamics. doi:10.1007/s10236-014-0745-2.

Olabarrieta, M., J. C. Warner, and N. Kumar (2011), Wave-current interaction in Willapa Bay, Journal of Geophysical Research, Oceans, 116, C12014, doi:10.1029/2011JC007387.

Olabarrieta, M., Warner, J.C., and Armstrong, B. (2012). Ocean-atmosphere dynamics during Hurricane Ida and Nor'Ida: an atmosphere-ocean-wave coupled modeling system application. Ocean Modelling, 43-44, pp 112-137.

Peng, S.Q., D.L. Liu, Z.B. Sun and Y.N. Li, (2012). Recent advances in regional air-sea coupled models. Science China (Earth Sciences), 55(9), 1391-1405 http://earth.scichina.com:8080/sciDe/EN/Y2012/V55/I9/1391.

Poppe, L.J., McMullen, K.Y., Williams, S.J., and Paskevich, V.F., eds., 2014, USGS east-coast sediment analysis: Procedures, database, and GIS data (ver. 3.0, November 2014): U.S. Geological Survey Open-File Report 2005-1001, http://pubs.usgs.gov/of/2005/1001/; http://coastalmap.marine.usgs.gov/FlexWeb/national/usseabed/

Renault, L., Chiggiato, J., Warner, J.C., Gomez, M., Vizoso, G., and Tintoré1, J., (2012) Coupled Atmosphere-Ocean-Wave simulations of a storm event over the Gulf of Lion and Balearic Sea, Journal of Geophysical Research, Oceans, 117, C09019, doi:10.1029/2012JC007924.

Riggs, S.R., Cleary, W.J., Snyder, and Snyder, S.W. (1995) Influence on inherited geologic framework on barrier shoreface morphology and dynamics. Marine Geology 126, 213-234.

Rogers, R., S. Aberson, M. Black, P. Black, J. Cione, P. Dodge, J. Gamache, J. Kaplan, M. Powell, J. Dunion, E. Uhlhorn, N. Shay, and N. Surgi, 2006: The intensity forecasting experiment: a NOAA multiyear field program for improving tropical cyclone intensity forecasts. Bull. Amer. Meteor. Soc., 87, 1523-1537.

Schubert, C.E., Busciolano, Ronald, Hearn, P.P., Jr., Rahav, A.N., Behrens, Riley, Finkelstein, Jason, Monti, Jack, Jr., and Simonson, A.E., 2015, Analysis of stormtide impacts from Hurricane Sandy in New York: U.S. Geological Survey Scientific Investigations Report 2015-5036, 75 p., http://dx.doi.org/10.3133/sir20155036. 
Schwab, W.C., Baldwin, W.E., and Denny, J.F., 2016, Assessing the impact of Hurricanes Irene and Sandy on the morphology and modern sediment thickness on the inner continental shelf offshore of Fire Island, New York: U.S. Geological Survey Open-File Report 2015-1238, 15 p., http://dx.doi.org/10.3133/ofr20151238.

Schwab, W.C., Baldwin, W.E., and Denny, J.F. (2014a) Maps showing the change in modern sediment thickness on the Inner Continental Shelf Offshore of Fire Island, New York, between 1996-97 and 2011: U.S. Geological Survey Open-File Report 2014-1238, http://dx.doi.org/10.3133/ofr20141238.

Schwab, W.C., Baldwin, W.E., Denny, J.F., Hapke, C.J., Gayes, P.T., List, J.H., and Warner, J.C. (2014b) Modification of the Quaternary stratigraphic framework of the inner-continental shelf by Holocene marine transgression-An example offshore of Fire Island, New York. Marine Geology 355, 346-360.

Schwab, W.C., Baldwin, W.E., Hapke, C.J., Lentz, E.E., Gayes, P.T., Denny, J.F., List, J.H., Warner, J.C. (2013) Geologic evidence for onshore sediment transport from the inner-continental shelf: Fire Island, New York. Journal of Coastal Research 26 (3), 536-544.

Schwab, W.C., Thieler, E.R., Allen, J.R., Foster, D.S., Swift, B.A., and Denny, J.F. (2000) Influence of inner-continental shelf geologic framework on the evolution and behavior of the barrier-island system between Fire Island Inlet and Shinnecock Inlet, Long Island, New York: Journal of Coastal Research, 16, 408422.

Shchepetkin, A. F., McWilliams, J.C., 2005. The Regional Oceanic Modeling System: A split-explicit, free-surface, topography-following coordinate oceanic model. Ocean Modeling 9, 347-404 doi:10.1016/j.ocemod.2004.08.002.

Shchepetkin, A. F., McWilliams, J. C., 2009. Correction and commentary for “Ocean forecasting in terrain-following coordinates: Formulation and skill assessment of the regional ocean modeling system” by Haidvogel et al., J. Comp. Phys. 227, pp. 3595-3624.”. Journal of Computational Physics. 228, 8985-9000.

Sopkin, K.L., Stockdon, H.F., Doran, K.S., Plant, N.G., Morgan, K.L.M., Guy, K.K., and Smith, K.E.L., 2014, Hurricane Sandy-Observations and Analysis of Coastal Change: U.S. Geological Survey Open-File Report 2014-1088, 54p., http://dx.doi.org/10.3133/ofr20141088.

Stone, B.D., and Borns, H.W. (1986) Pleistocene glacial and interglacial stratigraphy of New England, Long Island, and adjacent Georges Bank and Gulf of Maine. In, Sibraba, V., Bowen, D.Q., and Richmond, G.M., (Eds.), Quaternary Glaciations in the Northern Hemisphere. Pergamon Press, Oxford, pp. 38-52. 
833

834

835

836

837

838

839

840

841

842

843

844

845

846

847

848

849

850

851

852

853

854

855

856

857

858

859

860

861

862

863

864

865

866

867

868

869

870

871

872

873

874

875

876

877
Stubblefield, W.L., McGrail, D.W., and Kersey, D.G. (1984) Recognition of transgressive and post-transgressive sand ridges on the New Jersey continental shelf. In, Tillman, R.W., Siemers, C.T., (Eds.) Siliclastic shelf sediments. SEPM Special Publication 34, pp. 1-23.

Sullivan, C.M., Warner, J.C., Martini, M.A., Voulgaris, G., Work, P.A., Haas, K.A., and Hanes, D.H. (2006) "South Carolina Coastal Erosion Study Data Report for Observations October 2003 - April 2004” U.S. Geological Survey Open-File Report 2005-1429, http://pubs.usgs.gov/of/2005/1429/.

Swift, D.J.P., and Field, M.E. (1981) Evolution of a classic sand ridge field: Maryland sector North American inner shelf. Sedimentology 28, 461-482.

Swift, D.J.P. and Freeland, G.L. (1978) Current lineations and sand waves on the inner shelf, Middle Atlantic Bight of North America. Journal of Sedimentary Petrology 48, 1257-1266.

Taylor, P.K., Yelland, M.J., 2001. The dependence of sea surface roughness on the height and steepness of the waves. J. Phys. Oceanogr. 31, 572-590.

Teague, W. J., E. Jarosz, D. W. Wang, and D. A. Mitchell, 2007: Observed oceanic response over the upper continental slope and outer shelf during Hurricane Ivan. J. Phys. Oceanogr., 37, 2181-2206.

Uchiyama, Y., McWilliams, J.C., Shchepetkin, A.F., 2010. Wave-current interaction in an oceanic circulation model with a vortex-force formalism: application to the surf zone. Ocean Modeling, doi: 10.1016/j.ocemod.2010.04.002.

Wada, A., N. Kohno, and Y. Kawai, 2010: Impact of wave-ocean interaction on Typhoon Hai-Tang in 2005. SOLA, 6A, 13-16.

Wang Y, and Wu, C.C. (2004) Current understanding of tropical cyclone structure and intensity changes - a review. Meteorol Atmos Phys 87:257-278. doi:10.1007/s00703-003-0055-6.

Warner, J.C., Sherwood, C.R., Signell, R.P., Harris, C., Arango, H.G., 2008. Development of a three-dimensional, regional, coupled wave, current, and sediment-transport model. Computers and Geosciences 34, 1284-1306.

Warner, J.C., Armstrong, B., He, R., and Zambon, J. (2010). Development of a Coupled Ocean-Atmosphere-Wave-Sediment Transport (COAWST) Modeling System, Ocean Modelling, 35, 230-244. (http://woodshole.er.usgs.gov/projectpages/cccp/public/COAWST.htm) 
878

879

880

881

882

883

884

885

886

887

888

889

890

891

892

893

894

895

896

897

898

899

900

901

902

903

904

905

906

907

908

909

910

911

912

913

914

915

916

917

918

919

920

921

Williams, S.J. (1976) Geomorphology, shallow subbottom structure and sediments of the Atlantic inner-continental shelf off Long Island, New York. Technical Paper No. 76-2. U.S. Army Corps of Engineers, CERC, Fort Belvoir, Virginia, 123 pp.

Wren, P.A., and Leonard, L.A. (2005). Sediment transport on the mid-continental shelf in Onslow Bay, North Carolina during Hurricane Isabel. Estuarine, Coastal, and Shelf Science, 63, 43-56.

Zambon, J.B., He, R., and Warner, J.C. (2014a). Investigation of Hurricane Ivan using the Coupled Ocean-Atmosphere-Wave-Sediment Transport (COAWST) Model, Ocean Dynamics, doi:10.1007/s10236-014-0777-7.

Zambon, J. B., R. He, and J. C. Warner (2014)b, Tropical to extratropical: Marine environmental changes associated with Superstorm Sandy prior to its landfall, Geophys. Res. Lett., 41, doi:10.1002/2014GL061357.

Figure 1. Map of US East coast showing track of Hurricane Sandy (black line with -xand timed positions), $100 \mathrm{~m}$ isobaths (thin black line), and numerical results of (A) maximum water level surge (increase of water level above normal tide) and (B) timing of maximum surge. Locations shown in (A) for water level stations of Figure 5 (WH: Woods Hole; BA: Battery; SH: Sandy Hook; LE: Lewes; and CH: Charleston).

Figure 2. Site map insert identifies location of principal study area offshore of Fire Island, NY. Map shows backscatter intensity revealing gravelly lag deposit suggested to represent seaward extent of an outwash lobe that liberated sediment able to be form shoreface connected ridges along western end of the island, eastern end is comprised of sorted bedforms extending offshore across study region. (Figure modified from Schwab et al., 2016).

Figure 3. Map (A) shows the interpolated bathymetric surface generated from multibeam echosounder data collected offshore of Fire Island, New York in January 2014 (Schwab, et al., 2015). Bathymetry is in meters (m) below the North Atlantic Vertical Datum of 1988 (NAVD 88). Maps (B) and (C) illustrate isopachs of modern sediment thickness derived from seismic-reflection data collected in 2011 and 2014, respectively. These isopachs are overlain on the sun-illuminated bathymetric surface shown in Map (A). West of Watch Hill the modern sand deposit is organized into a series of shorefaceattached sand ridges oriented obliquely to the shoreline. The Pleistocene glacial outwash units from which the modern sands were reworked are exposed in the troughs between the ridges and across other portions of the inner shelf where the modern deposit is absent. The presence of sorted bedforms on the inner continental shelf east of Watch Hill is indicative of this active erosion of the glacial outwash units (Schwab and others, 2014). Figure modified from Schwab, Baldwin, and Denny (2014). 
922 Figure 4. Numerical model grids for both ROMS and SWAN configured for refined

923 concurrent coupling. Every 10th grid line shown for clarity, with grid resolution

924 approximately: A) USE, 5 km; B) NYB, 700 m; and C) SHF, 100 m.

Figure 5. Time series of water levels (m; MSL) at 5 locations along US East coast showing observed data (blue), predicted full storm dynamics (red Run 1), and predicted tide only (black Run 2). Locations are shown on Figure 1A.

Figure 6. Time series of significant wave heights at NDBC buoys (positions shown in Figure 7) for observed (blue lines) and predicted (black lines).

Figure 7. Map of US East coast showing track of Hurricane Sandy (black line with -xand timed positions), 100m isobaths (thin black line), and numerical results of predicted (A) maximum wave heights and (B) times of maximum waves that occurred during the storm simulation.

Figure 8. Comparison of coastal HFRADAR derived surface currents (red) to COAWST surface currents (black), with wind vectors (blue) at (A) October 29 at 0000 UTC and (B) October 29 at 1800 UTC.

Figure 9. Maximum combined bottom stress during Hurricane Sandy for (A) US East and (B) NYB and SHF (thin outline) grids. Wider range scale in (B) reflects higher resolution of predictions simulated using NYB and SHF grids.

Figure 10. Color image of mean bottom grain diameter (m) with arrows showing net suspended-sediment fluxes for A) Gulf of Maine, and B) Mid Atlantic Bight.

Figure 11. Changes to seafloor sediment thickness for A) US East (5km) and B) NYB $(700 \mathrm{~m})$ grid. Panel (A) uses an evolved initial sediment distribution and panel (B) was initialized uniformly. Results are consistent with deposition in the Hudson Shelf Valley and erosion on the flanks. Change magnitudes $<0.001 \mathrm{~m}$ not shown in (A) for clarity.

Figure 12. Comparison of change in modern sediment thickness change for (A) model results along entire length of offshore of Fire Island during Hurricane Sandy; (B) rotated model results along western Fire Island; and (C) measured from seismic-reflection data [2011-2014]. 

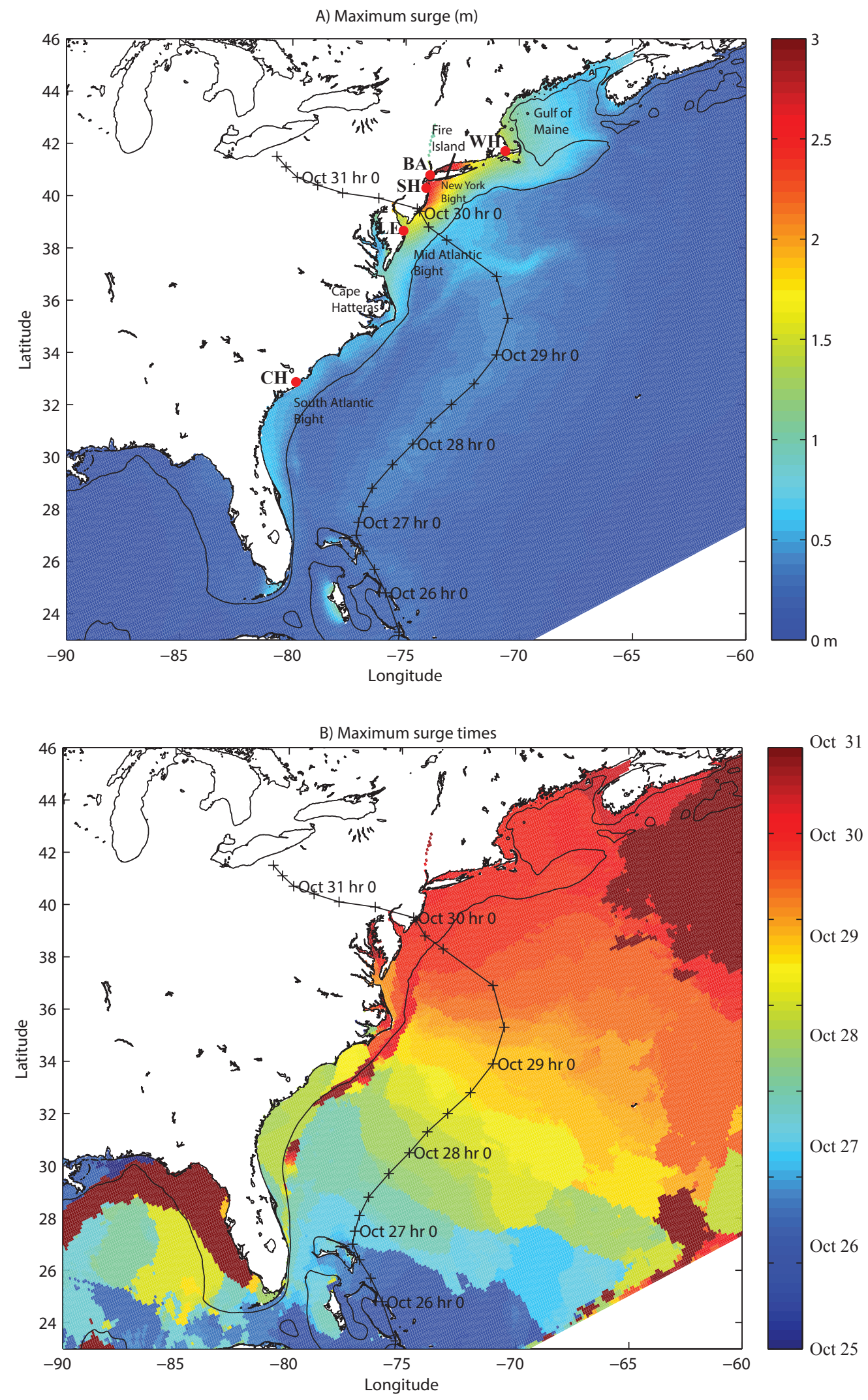


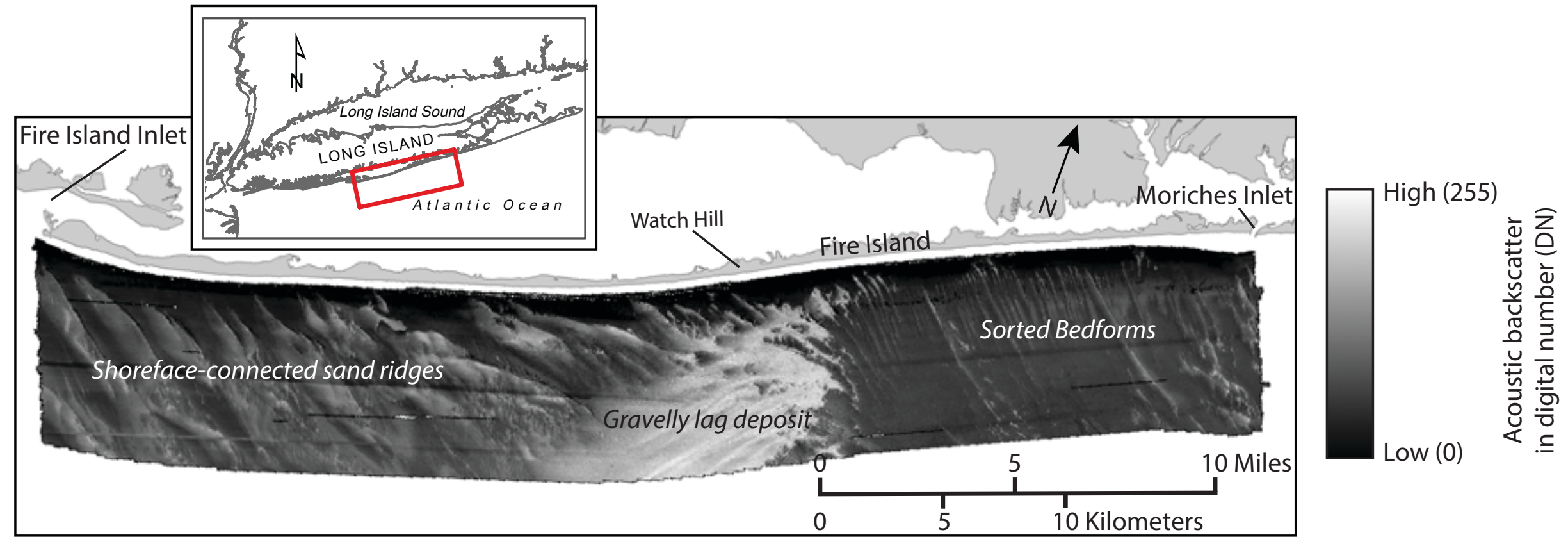



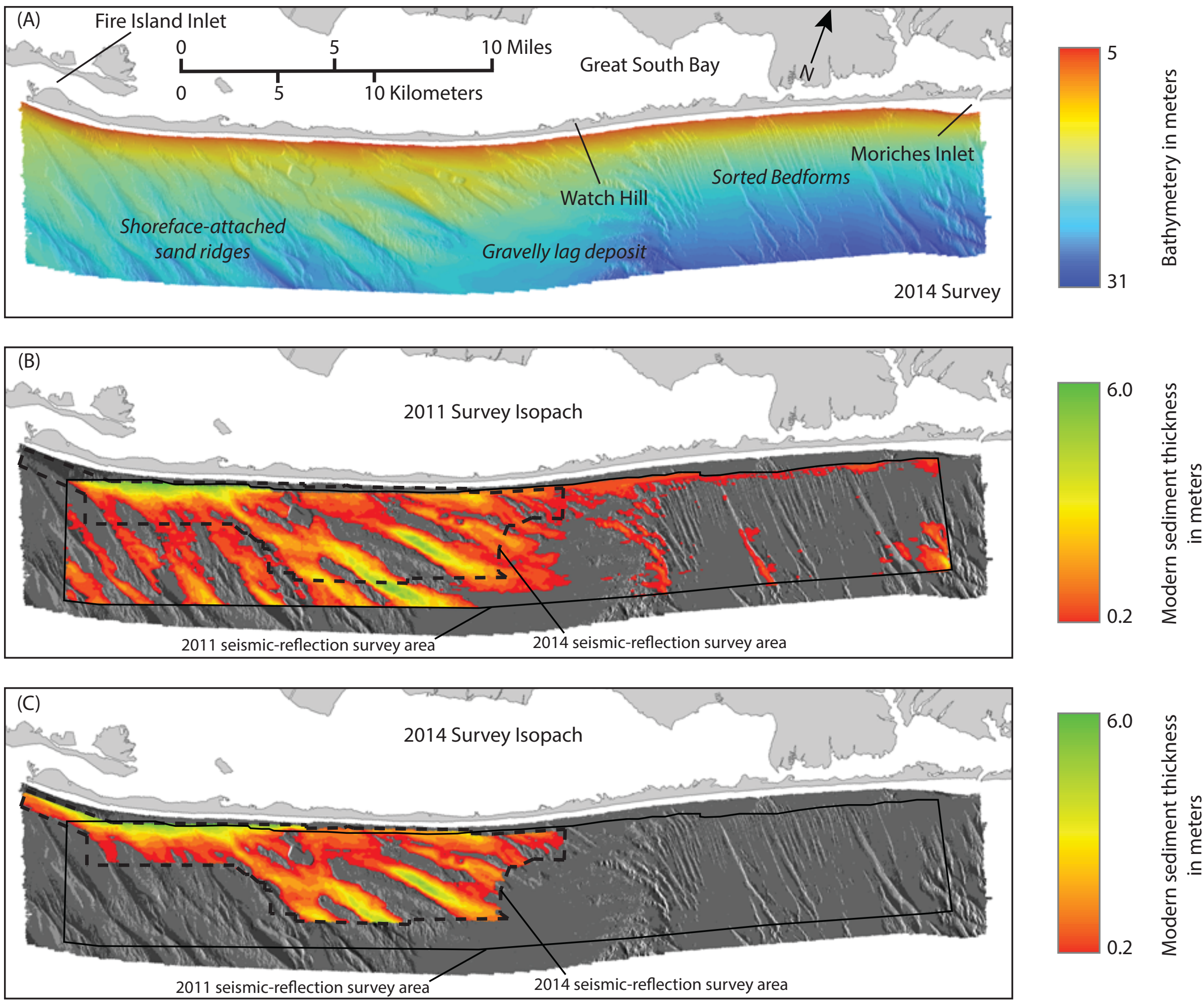

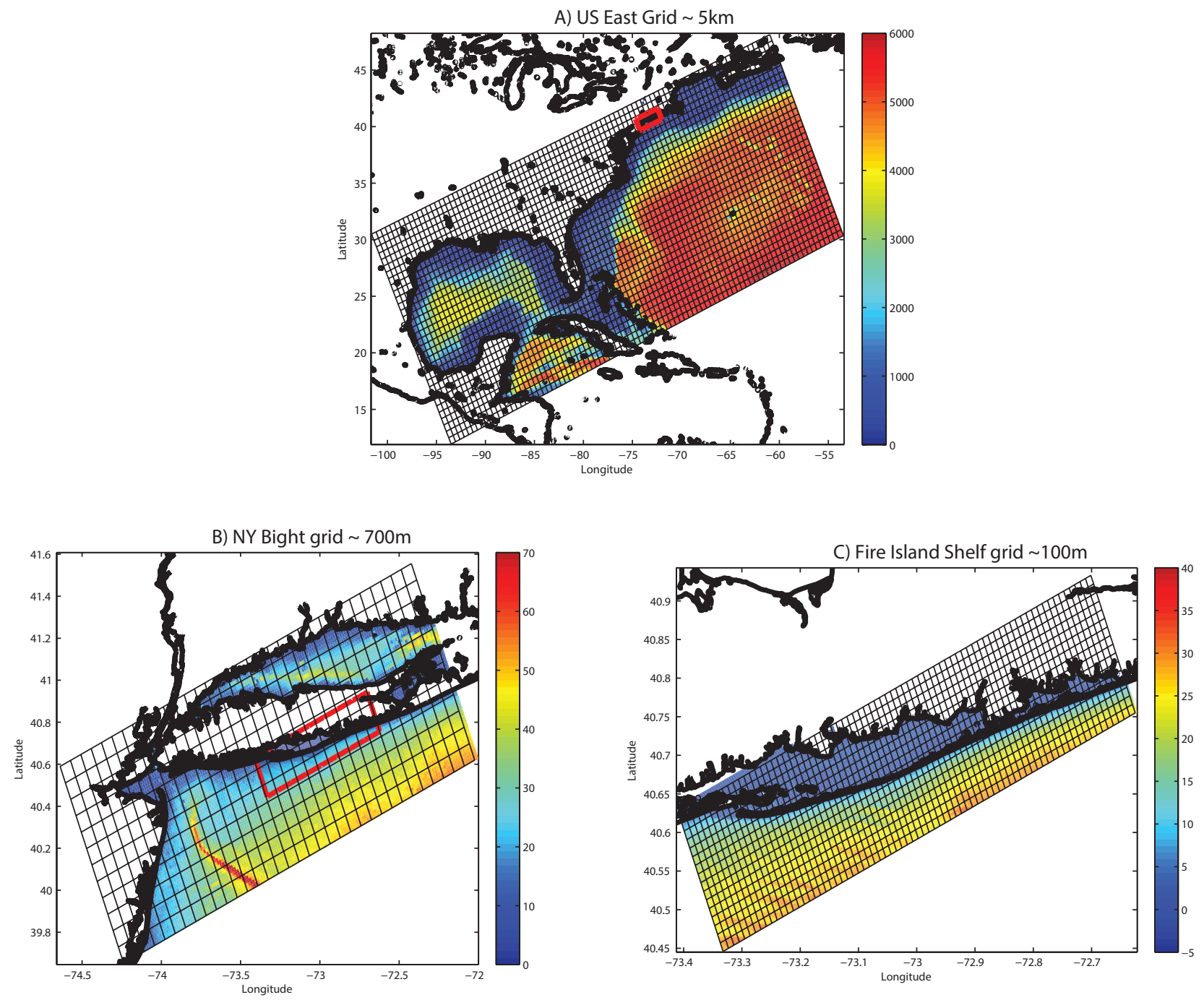

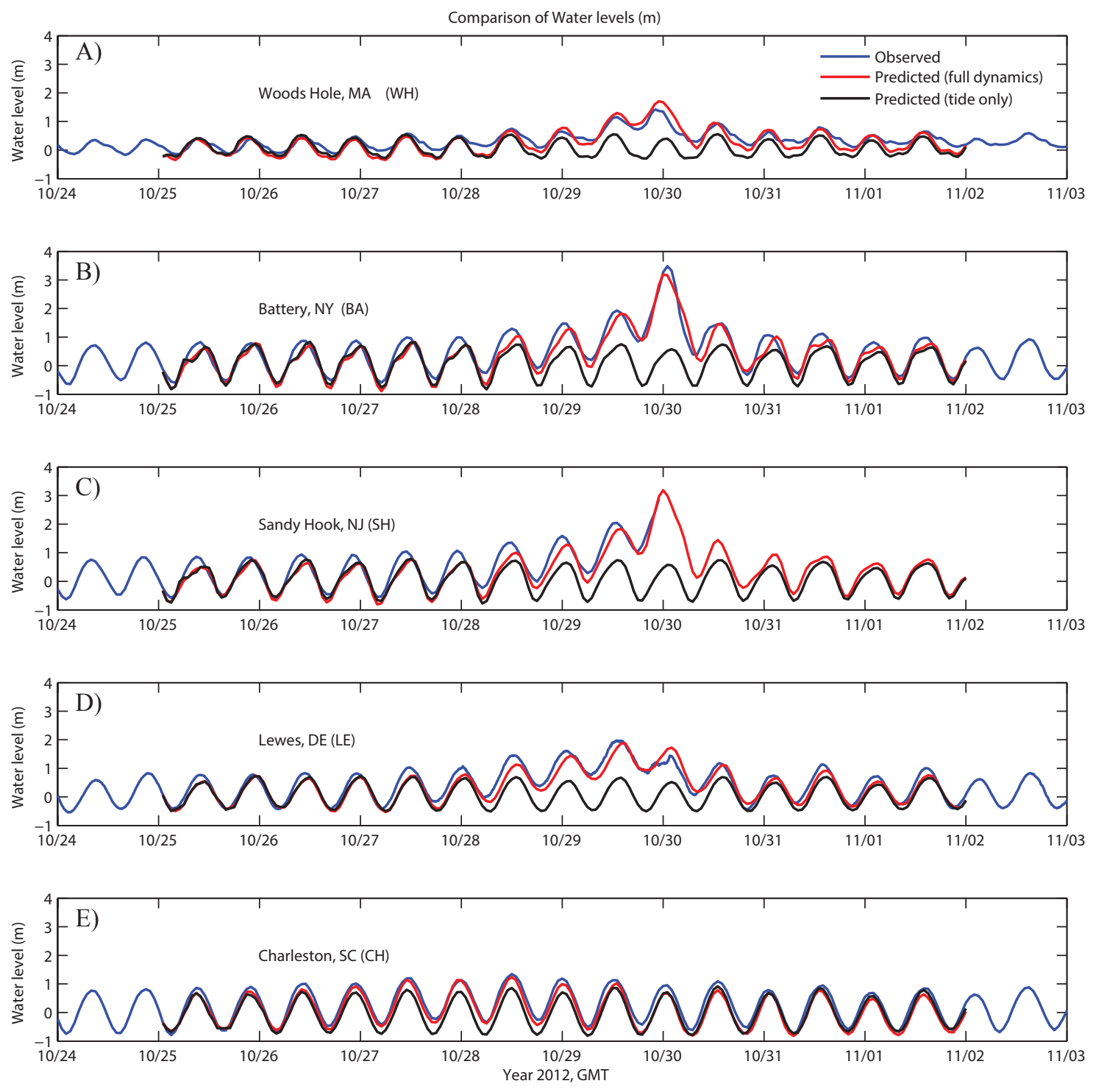

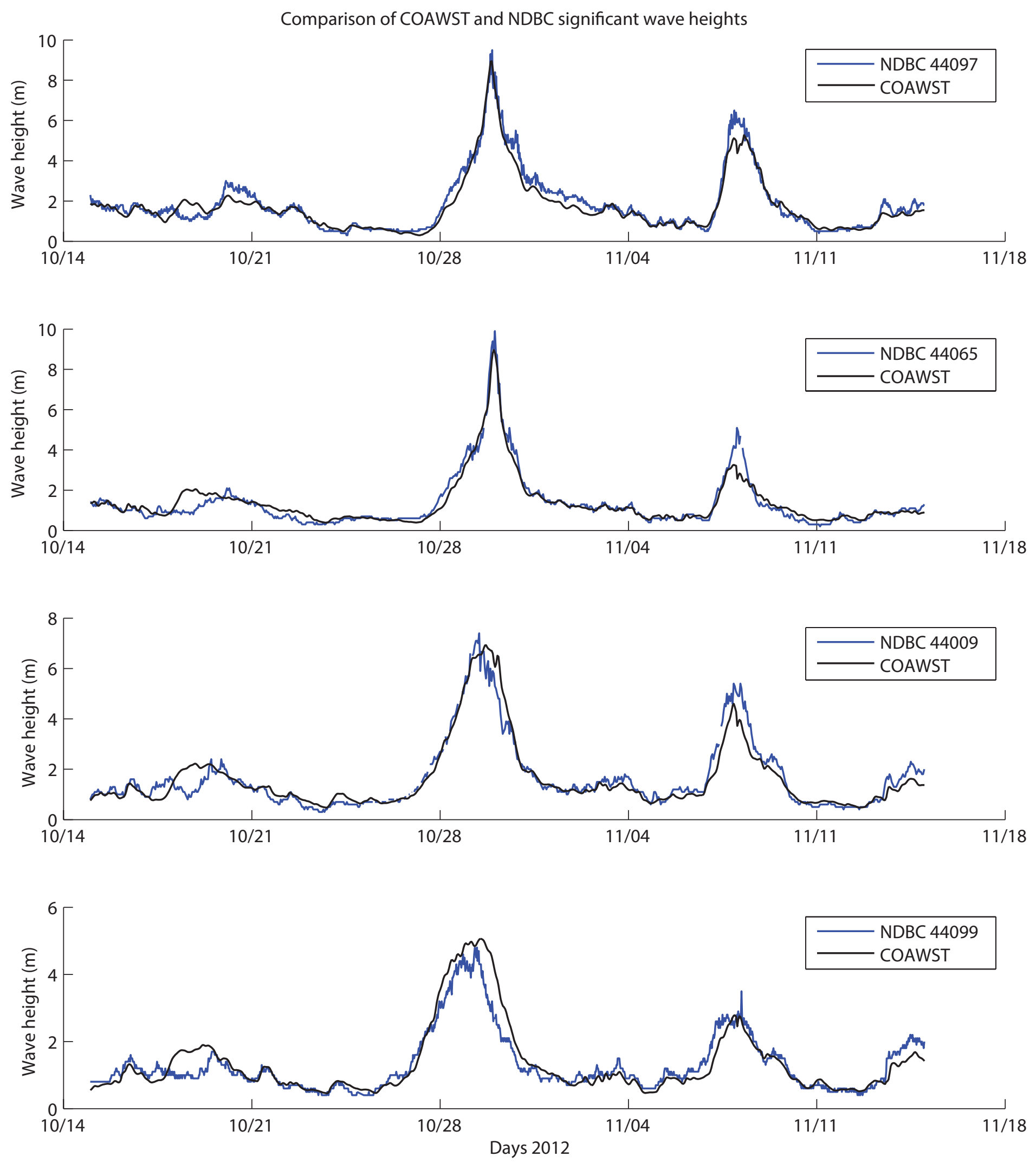


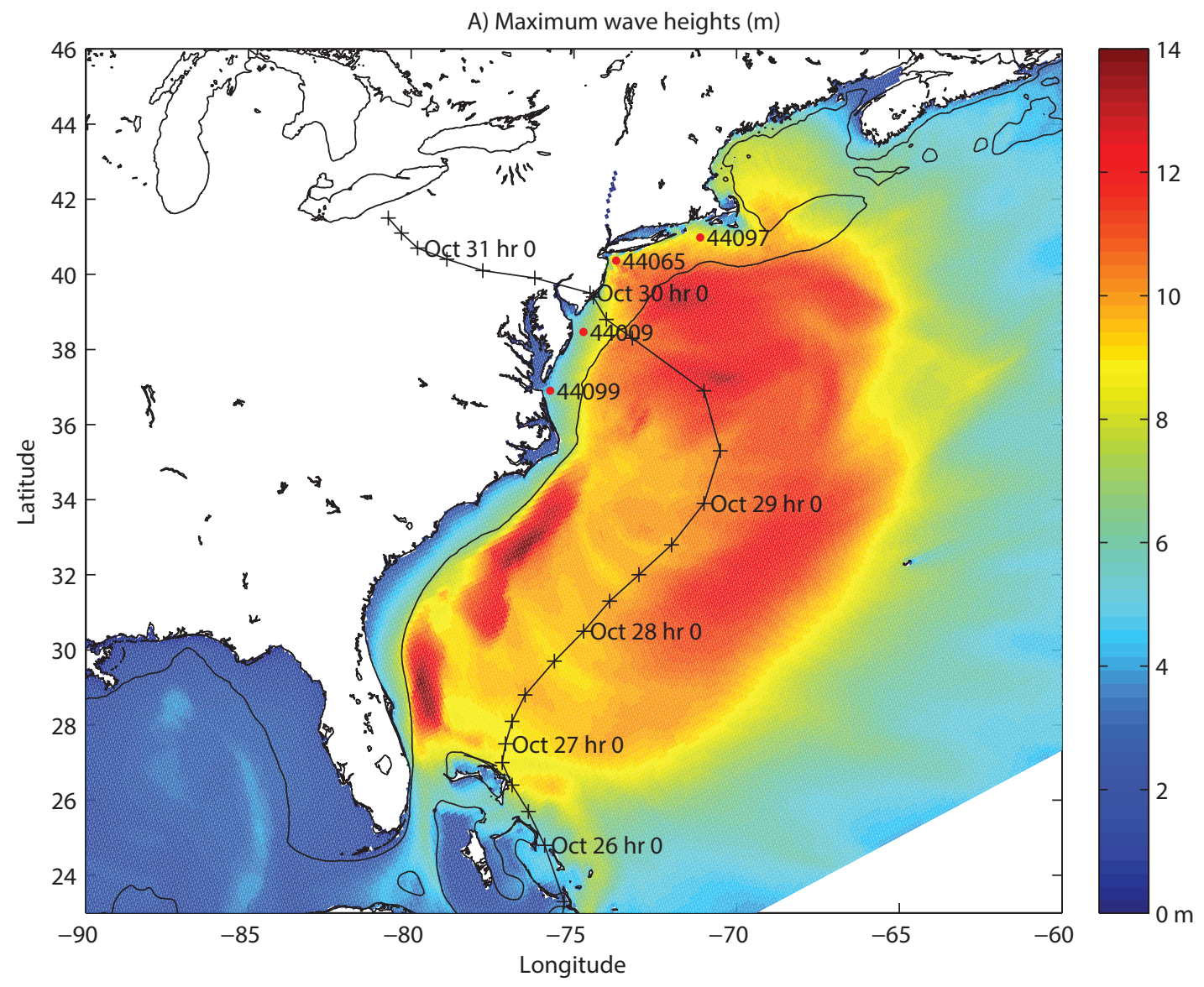

B) Maximum wave height times

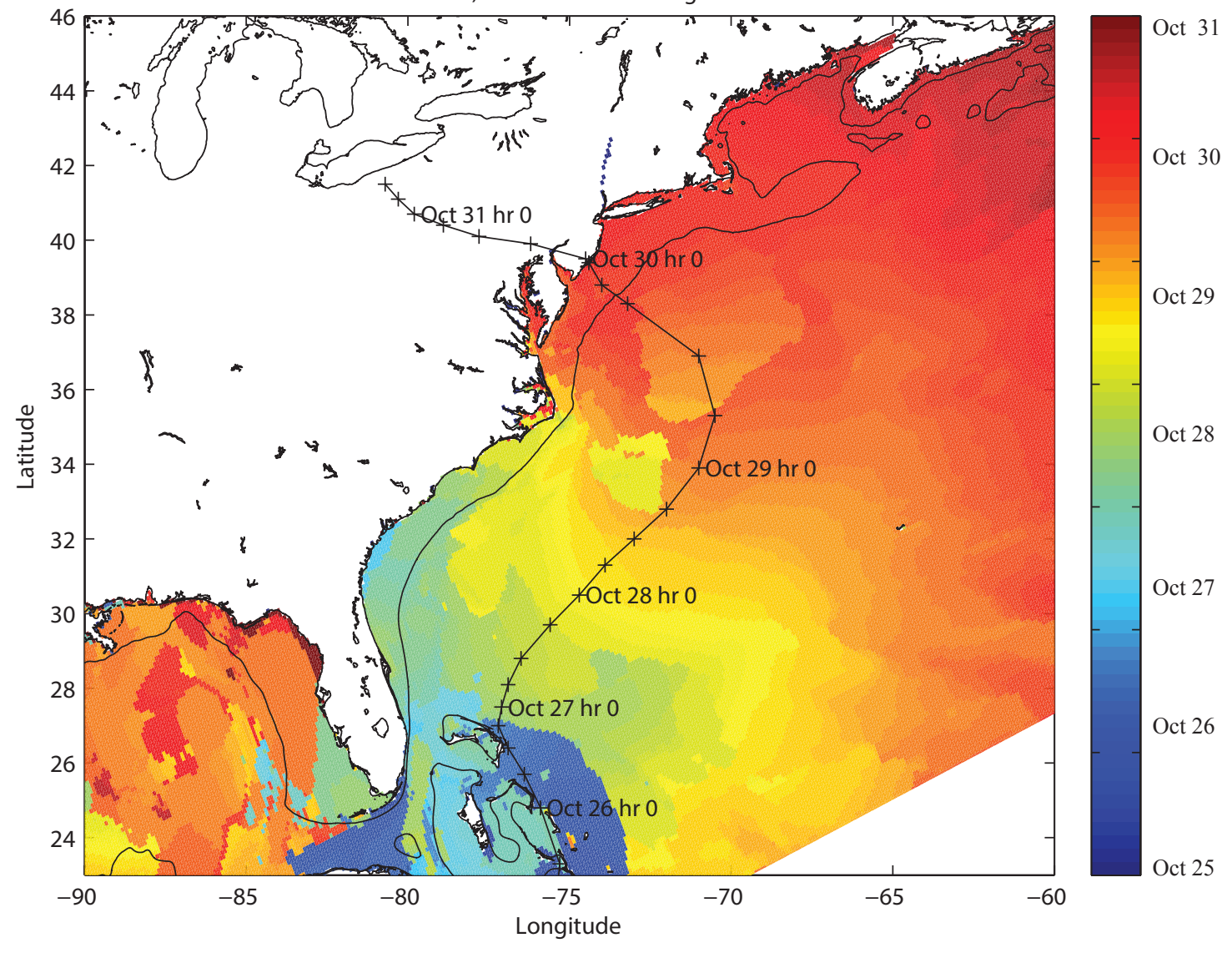


A) CODAR red, COAWST black, Wind blue, October 29, 2012 at 0000 UTC

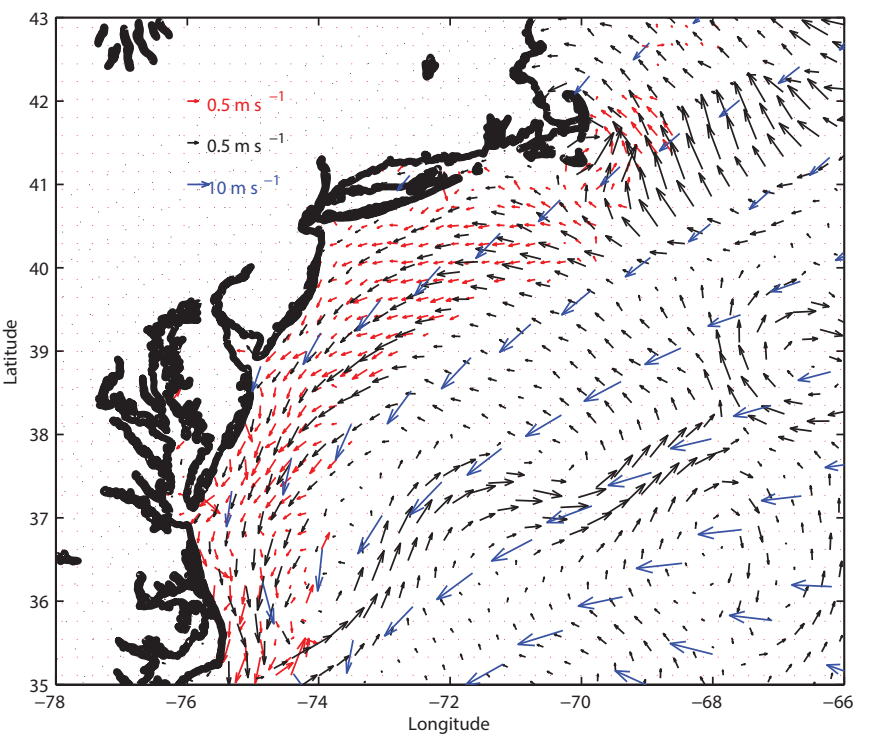

B) CODAR red, COAWST black, Wind blue, October 29, 2012 at 1800 UTC

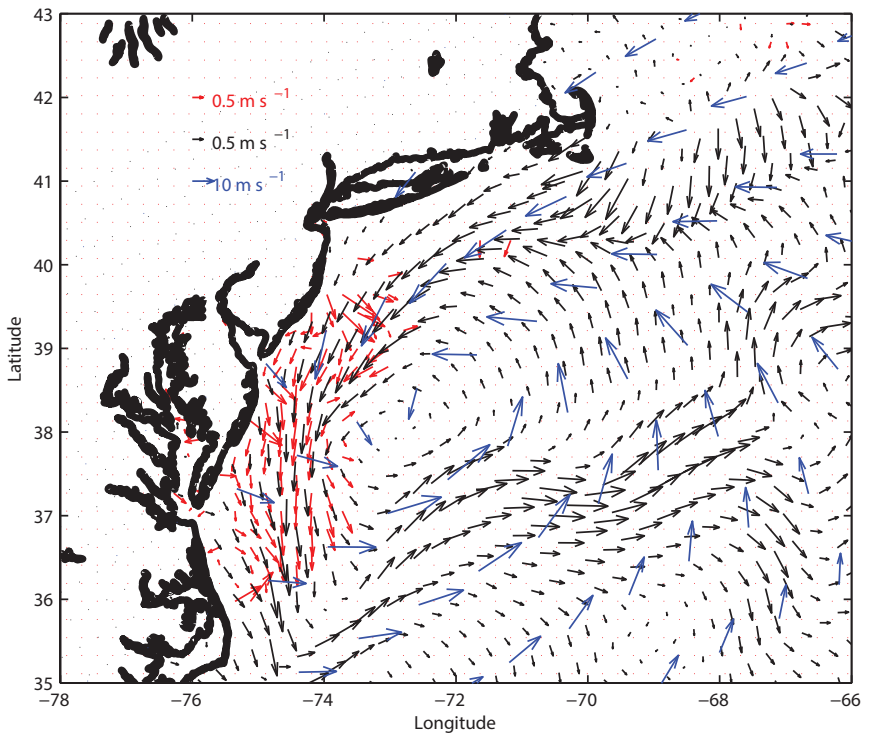


Model Prediction of maximum bottom stress $(\mathrm{Pa})$ during Hurricane Sandy
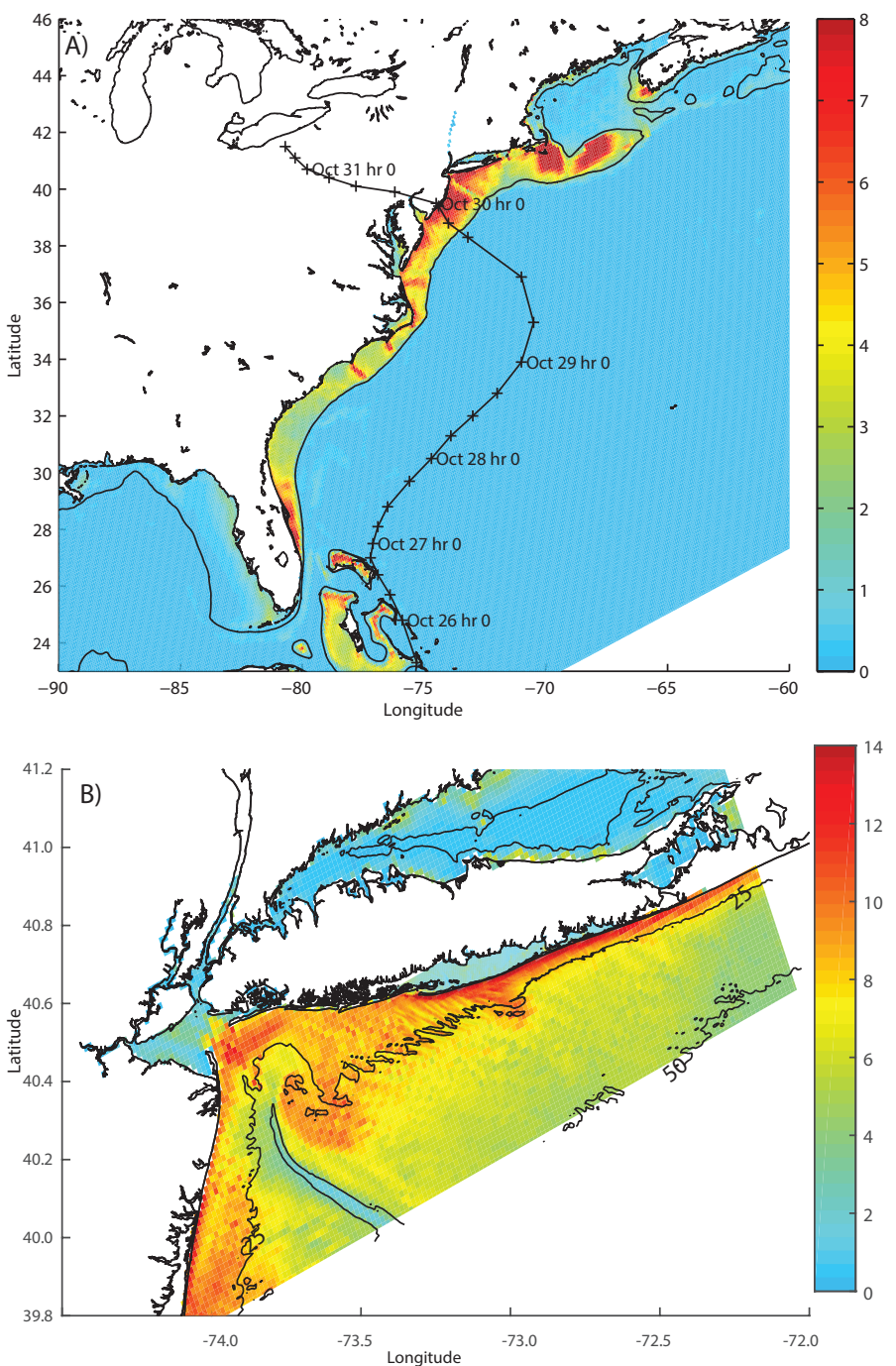

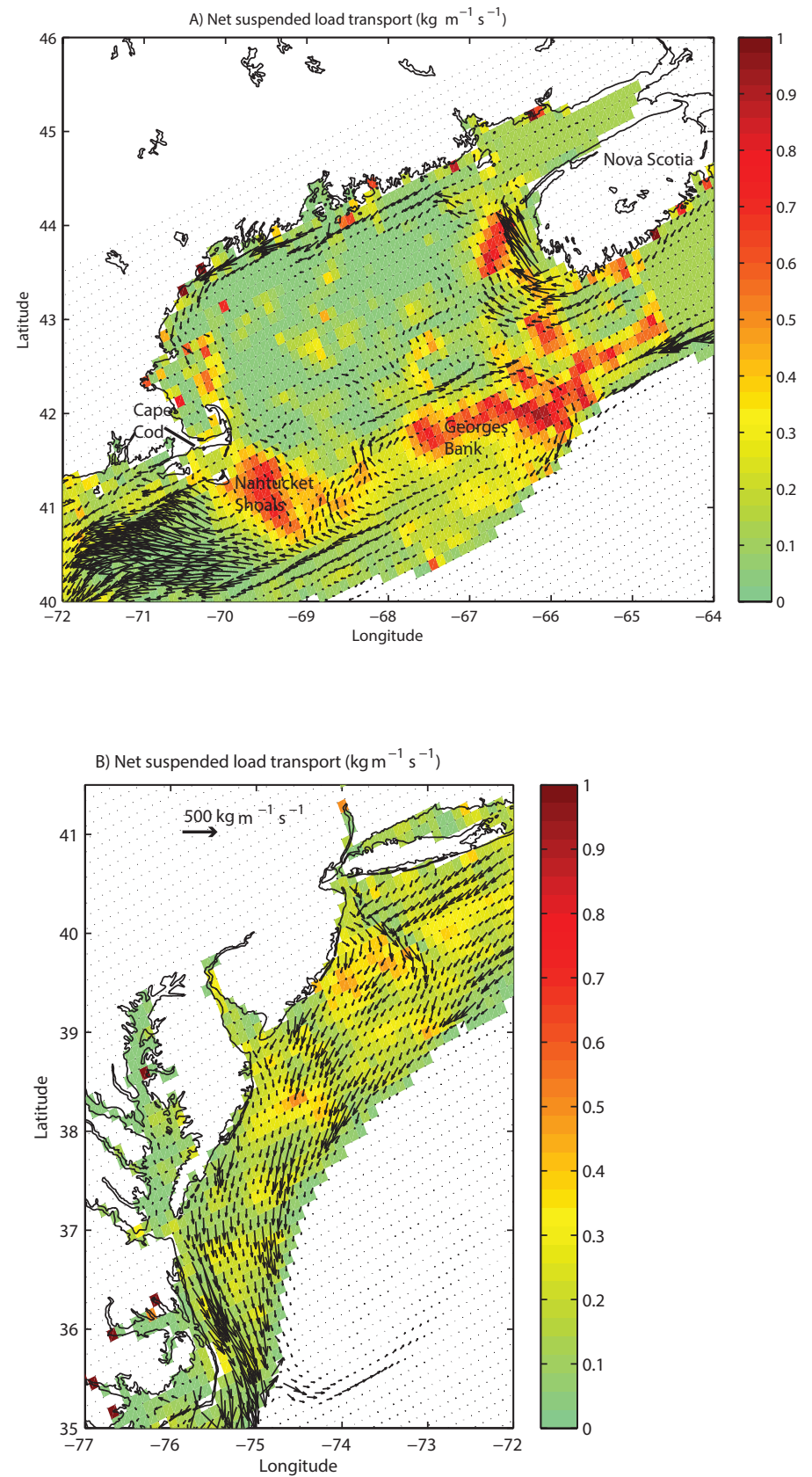

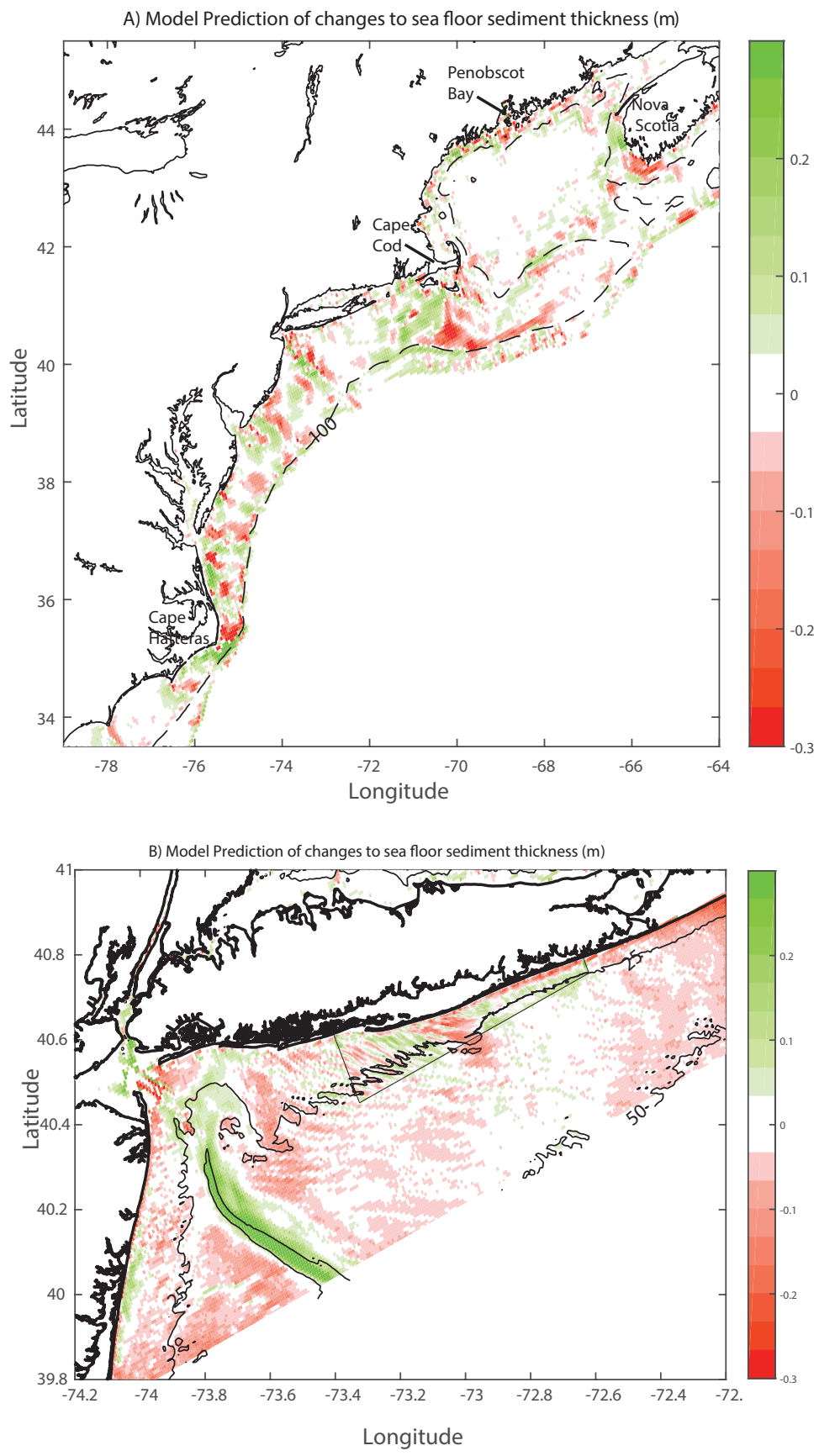


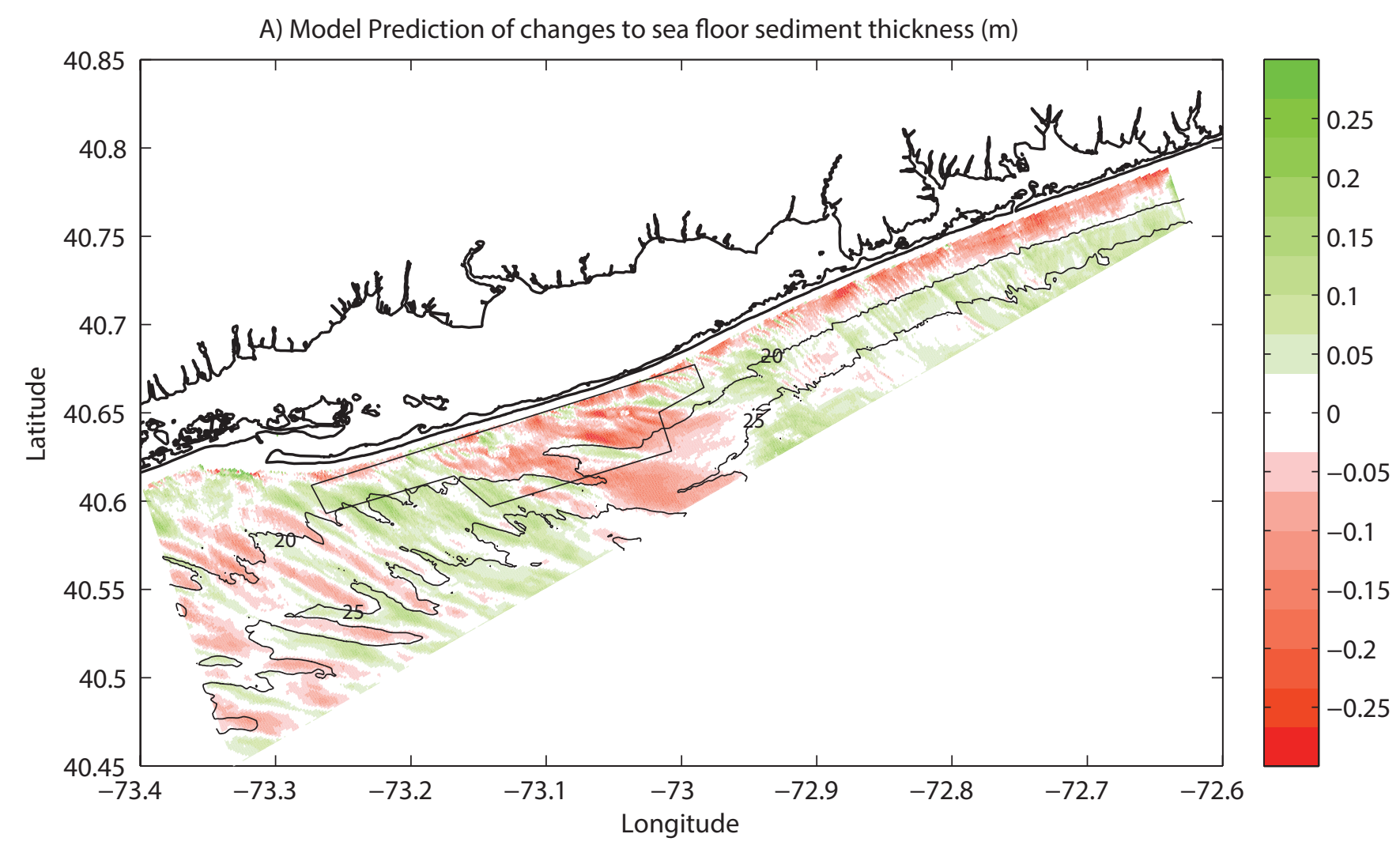




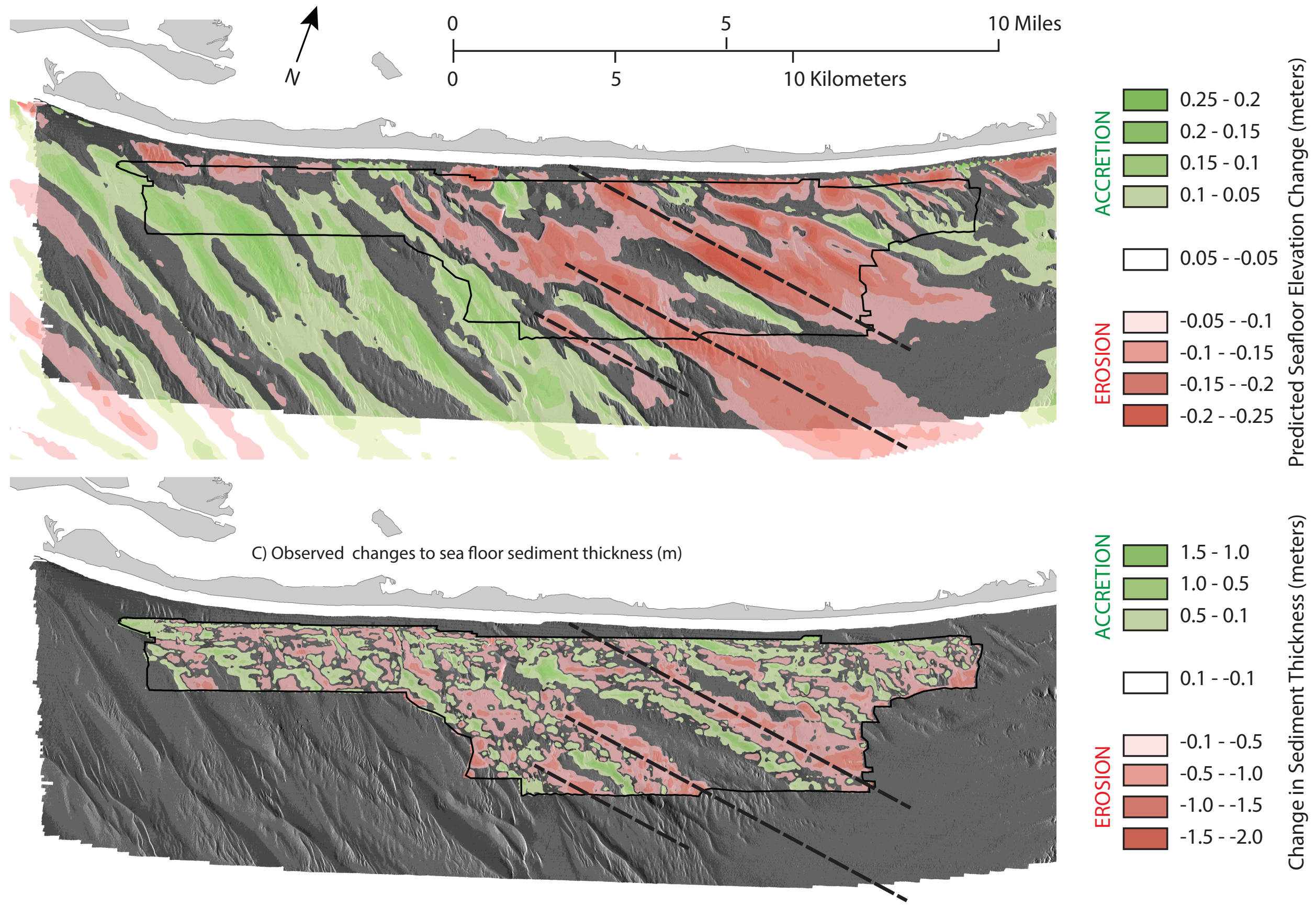

